\title{
Top-down constraints on atmospheric mercury emissions and implications for global biogeochemical cycling
}

S. Song ${ }^{1}$, N. E. Selin ${ }^{1,2}$, A. L. Soerensen ${ }^{3,4}$, H. Angot $^{5}$, R. Artz ${ }^{6}$, S. Brooks ${ }^{7}$, E.-G. Brunke ${ }^{8}$, G. Conley ${ }^{9}$,

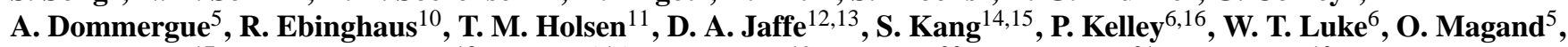
K. Marumoto ${ }^{17}$, K. A. Pfaffhuber ${ }^{18}$, X. Ren $^{6,16}$, G.-R. Sheu ${ }^{19}$, F. Slemr ${ }^{20}$, T. Warneke ${ }^{21}$, A. Weigelt ${ }^{10}$, P. Weiss-Penzias ${ }^{22}$, D. C. Wip ${ }^{23}$, and Q. Zhang ${ }^{24}$

${ }^{1}$ Department of Earth, Atmospheric and Planetary Sciences, Massachusetts Institute of Technology, Cambridge, MA, USA

${ }^{2}$ Engineering Systems Division, Massachusetts Institute of Technology, Cambridge, MA, USA

${ }^{3}$ Department of Environmental Health, Harvard School of Public Health, Boston, MA, USA

${ }^{4}$ Department of Applied Environmental Science, Stockholm University, Stockholm, Sweden

${ }^{5}$ Univ. Grenoble Alpes, CNRS, LGGE, Grenoble, France

${ }^{6}$ Air Resources Laboratory, National Oceanic and Atmospheric Administration, College Park, MD, USA

${ }^{7}$ Department of Mechanical, Aerospace and Biomedical Engineering, University of Tennessee Space Institute, Tullahoma, TN, USA

${ }^{8}$ South African Weather Service c/o CSIR, Stellenbosch, South Africa

${ }^{9}$ Center for Air Quality, Ohio University, Athens, OH, USA

${ }^{10}$ Institute of Coastal Research, Helmholtz-Zentrum Geesthacht, Geesthacht, Germany

${ }^{11}$ Department of Civil and Environmental Engineering, Clarkson University, Potsdam, NY, USA

${ }^{12}$ School of Science, Technology, Engineering and Mathematics, University of Washington, Bothell, WA, USA

${ }^{13}$ Department of Atmospheric Sciences, University of Washington, Seattle, WA, USA

${ }^{14}$ State Key Laboratory of Cryospheric Sciences, Cold and Arid Regions Environmental and Engineering

Research Institute, Chinese Academy of Sciences (CAS), Lanzhou, China

${ }^{15}$ CAS Center for Excellence in Tibetan Plateau Earth Sciences, Chinese Academy of Sciences, Beijing, China

${ }^{16}$ Cooperative Institute for Climate and Satellites, University of Maryland, College Park, MD, USA

${ }^{17}$ Environmental Chemistry Section, National Institute for Minamata Disease, Kumamoto, Japan

${ }^{18}$ Norwegian Institute for Air Research (NILU), Troms $\varnothing$, Norway

${ }^{19}$ Department of Atmospheric Sciences, National Central University, Jhongli, Taiwan

${ }^{20}$ Max Planck Institute for Chemistry, Air Chemistry Division, Mainz, Germany

${ }^{21}$ Institute of Environmental Physics, University of Bremen, Bremen, Germany

${ }^{22}$ Microbiology and Environmental Toxicology, University of California, Santa Cruz, CA, USA

${ }^{23}$ Anton de Kom Universiteit van Suriname, Paramaribo, Suriname

${ }^{24}$ Key Laboratory of Tibetan Environment Changes and Land Surface Processes, Institute of Tibetan

Plateau Research, Chinese Academy of Sciences, Beijing, China

Correspondence to: S. Song (song33@mit.edu)

Received: 26 November 2014 - Published in Atmos. Chem. Phys. Discuss.: 25 February 2015

Revised: 13 May 2015 - Accepted: 09 June 2015 - Published: 30 June 2015 
Abstract. We perform global-scale inverse modeling to constrain present-day atmospheric mercury emissions and relevant physiochemical parameters in the GEOS-Chem chemical transport model. We use Bayesian inversion methods combining simulations with GEOS-Chem and groundbased $\mathrm{Hg}^{0}$ observations from regional monitoring networks and individual sites in recent years. Using optimized emissions/parameters, GEOS-Chem better reproduces these ground-based observations and also matches regional overwater $\mathrm{Hg}^{0}$ and wet deposition measurements. The optimized global mercury emission to the atmosphere is $\sim 5.8 \mathrm{Gg} \mathrm{yr}^{-1}$. The ocean accounts for $3.2 \mathrm{Gg} \mathrm{yr}^{-1}$ ( $55 \%$ of the total), and the terrestrial ecosystem is neither a net source nor a net sink of $\mathrm{Hg}^{0}$. The optimized Asian anthropogenic emission of $\mathrm{Hg}^{0}$ (gas elemental mercury) is $650-1770 \mathrm{Mg} \mathrm{yr}^{-1}$, higher than its bottom-up estimates $\left(550-800 \mathrm{Mg} \mathrm{yr}^{-1}\right)$. The ocean parameter inversions suggest that dark oxidation of aqueous elemental mercury is faster, and less mercury is removed from the mixed layer through particle sinking, when compared with current simulations. Parameter changes affect the simulated global ocean mercury budget, particularly mass exchange between the mixed layer and subsurface waters. Based on our inversion results, we re-evaluate the longterm global biogeochemical cycle of mercury, and show that legacy mercury becomes more likely to reside in the terrestrial ecosystem than in the ocean. We estimate that primary anthropogenic mercury contributes up to $23 \%$ of present-day atmospheric deposition.

\section{Introduction}

Mercury $(\mathrm{Hg})$ is a ubiquitous trace metal that cycles between the atmosphere, ocean, land, and biosphere (Selin, 2009). Atmospheric mercury transports globally (Driscoll et al., 2013) and, in aquatic systems, can be converted to methylmercury, a bioaccumulative toxic compound (Mergler et al., 2007). Human activities have strongly affected the mercury global cycle by both unintentional and intentional releases (Streets et al., 2011). Since mercury deposited to terrestrial and ocean surfaces can remobilize, the atmosphere continues to be affected by its historical releases (Lindberg et al., 2007; Amos et al., 2013). Atmosphere-surface fluxes of mercury are still poorly constrained, limiting our ability to fully understand timescales of its global biogeochemical cycle (Pirrone et al., 2010; Mason et al., 2012). A better knowledge of these fluxes is important for assessing its impacts on humans and evaluating the effectiveness of policy actions (Selin, 2014).

Current estimates of mercury fluxes to the atmosphere are mainly built on a bottom-up approach. Anthropogenic inventories are based on emission factors, activity levels, and abatement efficiency (Pacyna et al., 2010; S. Wang et al., 2014; Muntean et al., 2014). Flux estimates from ocean and terrestrial surfaces extrapolate limited direct measurements to larger scales and use simplified process models (Mason,
2009; Kuss et al., 2011). The top-down or inverse approach, combining observations and atmospheric modeling, has been widely used to derive sources and sinks of greenhouse gases and ozone-depleting substances (Gurney et al., 2002; Xiao et al., 2010). Inverse studies have addressed mercury at a regional scale (Roustan and Bocquet, 2006; Krüger et al., 1999). For example, a hybrid inversion combining back trajectories and a regional chemical transport model (CTM) identified $\mathrm{Hg}^{0}$ emission using year-long urban observations (de Foy et al., 2012). This scheme was expanded to estimate sources of oxidized $\mathrm{Hg}$ (de Foy et al., 2014).

In this paper, we apply a top-down approach at global scale to quantitatively estimate present-day mercury emission sources (emission inversion) as well as key parameters in a CTM (parameter inversion), in order to better constrain the global biogeochemical cycle of mercury. Section 2 describes the overall methodology. We combine groundbased observations of atmospheric $\mathrm{Hg}^{0}$ (Sect. 2.1) and simulations with the GEOS-Chem global CTM (Sect. 2.2). Reference (also known as a priori) emissions are from GEOSChem parameterizations and agree well with bottom-up estimates (Sect. 2.3). We adopt a Bayesian inversion method (Sect. 2.4) to obtain the optimized (a posteriori) emissions, with a monthly time step, taking into account uncertainties associated with both reference emissions and groundbased observations (Sect. 2.6). Section 3 presents results and discussion. Comparisons of observations and model outputs are given in Sect. 3.1. The optimized emissions from ocean and terrestrial surfaces and from anthropogenic sources are shown in Sect. 3.2. We use results of the emission inversion to identify key uncertain model parameters, and optimize them in the parameter inversion (Sects. 2.5 and 3.3). Finally, we discuss implications of our inversion results for the global biogeochemical mercury cycle (Sect. 3.4) and summarize our conclusions (Sect. 4).

\section{Methods}

\subsection{Atmospheric mercury observations}

Tropospheric mercury exists mainly as gaseous elemental mercury (GEM) but also as two operationally defined species, gaseous oxidized mercury (GOM) and particlebound mercury (PBM) (Valente et al., 2007). Manual methods of measuring GEM or total gaseous mercury $(\mathrm{TGM}=\mathrm{GEM}+\mathrm{GOM})$ were applied in the 1970s (Slemr et al., 1981). High-frequency measurements (time resolution $<1$ h, e.g., using Tekran automated ambient air analyzers) became available in the 1990s and have substantially replaced manual sampling (time resolution of about several hours). We only use GEM and TGM observations in this study because we are not able to quantify the uncertainty in GOM and PBM measurements (Jaffe et al., 2014; McClure et al., 2014). 
We identify high-frequency observations of GEM and TGM concentration for our inversions using two criteria. First, we choose sites in rural/remote areas not strongly affected by local emissions. Second, we require that observations at different sites are minimally correlated (Brunner et al., 2012). Data sets are drawn from the Atmospheric Mercury Network (AMNet) (Gay et al., 2013), the Canadian Measurement Networks (including the Canadian Air and Precipitation Monitoring Network (CAPMoN) and other sites sponsored by Environment Canada) (Cole et al., 2014), and the European Monitoring and Evaluation Programme (EMEP) (Tørseth et al., 2012). We use data from 2009 to 2011, when all these networks were active. To expand spatial coverage of observations, we also collected data from individual sites for recent years (2007-2013). Some sites are included in the Global Mercury Observation System (GMOS) (Pirrone et al., 2013). All sites use Tekran analyzers, operated in sampling intervals of 5-30 min. We calculate Pearson's correlation coefficients between each pair of sites using hourly data. Several sites are excluded due to strong correlations within each other, as shown in Table S1 in the Supplement. Table 1 shows the names, locations, and affiliated networks of the 27 ground-based sites used in our inversion. Site locations are also plotted in Fig. 1. For most of these sites GEM data are used, and for a few sites where GEM data are not available we use TGM data (see Table 1). The concentration difference between measured GEM and TGM concentrations in remote near-surface air is usually < $1 \%$ (Lan et al., 2012; Fu et al., 2012a; Weigelt et al., 2013; Steffen et al., 2014) and thus we do not distinguish between measured GEM and TGM concentrations and use $\mathrm{Hg}^{0}$ to represent them in the paper. These sites are all uncorrelated or only weakly correlated $\left(-0.3<r<0.4, n=10^{3}-10^{4}\right.$ ) (see Table S2 in the Supplement).

Original observational data are converted into hourly averages and then into monthly averages (Fig. S1 in the Supplement). We require $>30 \mathrm{~min}$ data to derive an hourly average and $>10$-day data to derive a monthly average. Where full data are available, median values are used to suppress the influence of high $\mathrm{Hg}^{0}$ due to local or regional pollution events (Weigelt et al., 2013; Jaffe et al., 2005) or occasional low $\mathrm{Hg}^{0}$ due to non-polar depletion events (Brunke et al., 2010). For a few individual sites (see Table 1), the original data are not available and monthly arithmetic means are used. Finally, multiple-year averages are calculated. $\mathrm{Hg}^{0}$ concentrations are given in nanograms per cubic meter at standard temperature and pressure.

Four polar sites are included (ALT, ZEP, and ADY in the Arctic and TRS in Antarctica, see Table 1). Episodically low $\mathrm{Hg}^{0}$ is observed at these sites in polar spring (Cole et al., 2013; Pfaffhuber et al., 2012). These atmospheric mercury depletion events (AMDEs) result from rapid $\mathrm{Hg}^{0}$ oxidation and deposition driven by halogens (Steffen et al., 2008). Volatilization of the deposited $\mathrm{Hg}$ and the large quantities of imported mercury from circumpolar rivers to the Arctic

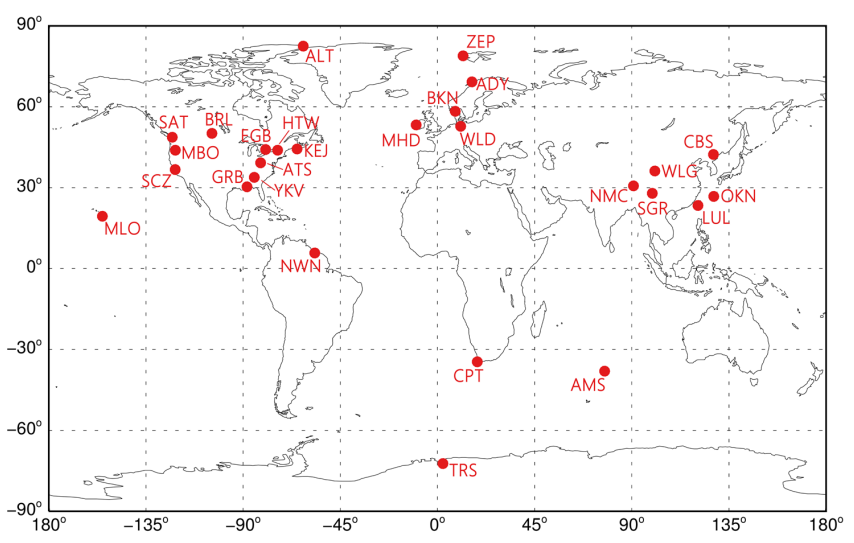

Figure 1. Locations of ground-based observational sites.

Ocean are hypothesized to contribute to the observed summer $\mathrm{Hg}^{0}$ peak in the Arctic region (Dastoor and Durnford, 2013; Fisher et al., 2012). The lack of understanding of the above physical and chemical processes limits GEOS-Chem's ability to reproduce $\mathrm{Hg}^{0}$ in the polar spring and summer. For these reasons we remove $\mathrm{Hg}^{0}$ data at polar sites for this period (i.e., March-September in the Arctic and OctoberMarch in Antarctica).

We also include three mountaintop sites (LUL, MBO, and MLO, see Table 1). These sites are affected by upslope surface air during the day and downslope air from the free troposphere at night (Sheu et al., 2010; Fu et al., 2010). The downslope air usually contains higher levels of GOM than the upslope air due to oxidation of $\mathrm{Hg}^{0}$ to GOM in the free troposphere (Timonen et al., 2013). Therefore, $\mathrm{Hg}^{0}$ at mountaintop sites peaks in the afternoon whereas GOM peaks between midnight and early morning (Fig. S2 in the Supplement), showing an opposite diurnal pattern to most lowelevation sites (Lan et al., 2012). The minimum hourly $\mathrm{Hg}^{0}$ at night is calculated to be $\sim 90 \%$ of the all-day average. Thus, to represent $\mathrm{Hg}^{0}$ modeled at a vertical layer in the free troposphere (this layer is obtained by matching observed air pressure), the observed mountaintop $\mathrm{Hg}^{0}$ data are multiplied by 0.9 .

We do not use over-water $\mathrm{Hg}^{0}$ observations (i.e., from ship cruises) in the inversion because they are very limited and usually cover large areas, making their observational errors difficult to estimate. Instead, we use over-water observations as an independent check of our inversion results. The North Atlantic Ocean is the most densely sampled ocean basin. Soerensen et al. (2012) assembled $\mathrm{Hg}^{0}$ measurements from 18 ship cruises in this region during 1990-2009 and found a statistically significant decrease of $-0.046 \pm 0.010 \mathrm{ng} \mathrm{m}^{-3} \mathrm{yr}^{-1}$. However, previous GEOSChem simulations of $\mathrm{Hg}^{0}$ concentration did not take this multidecadal trend into account in evaluating its seasonal variability (Soerensen et al., 2010a). Here we add a new ship cruise and adjust observed $\mathrm{Hg}^{0}$ concentrations $\left(\mathrm{Hg}_{\mathrm{obs}}^{0}\right)$ from 


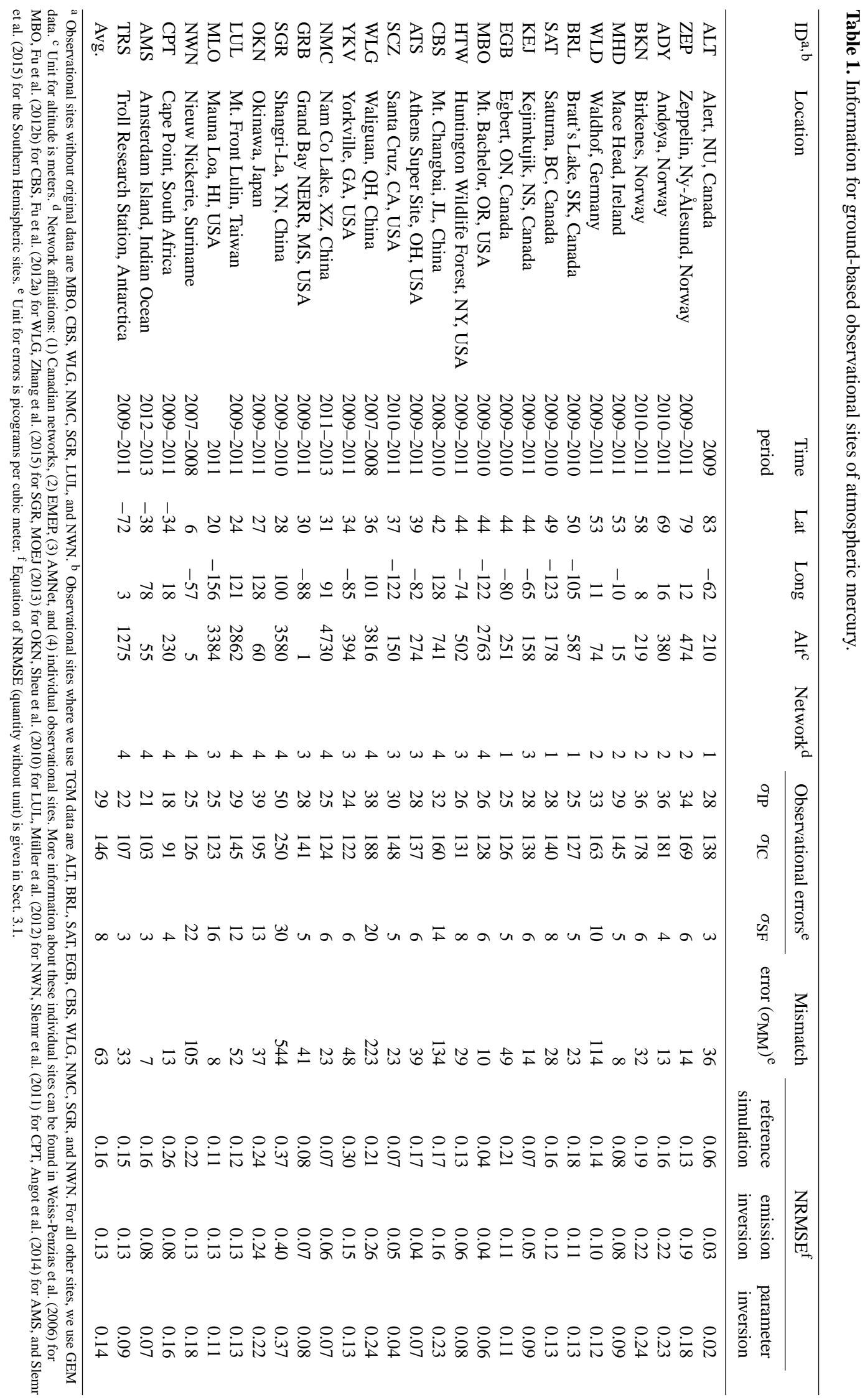


all 19 ship cruises to $\mathrm{Hg}^{0}$ levels consistent with year 2009 based on a fitted decline trend (Table S3 and Fig. S3 in the Supplement). Seasonal variation is estimated by dividing the normalized $\mathrm{Hg}^{0}\left(\mathrm{Hg}_{\text {nor }}^{0}\right)$ by month of measurement. As shown in Fig. 2, $\mathrm{Hg}_{\text {nor }}^{0}$ are smaller and show less seasonal variability compared to $\mathrm{Hg}_{\mathrm{obs}}^{0}$.

\subsection{GEOS-Chem model}

GEOS-Chem (v9-02) is a CTM driven by assimilated meteorological fields from the NASA Goddard Earth Observing System (Bey et al., 2001). The original GEOS-5 has a resolution of $1 / 2^{\circ} \times 2 / 3^{\circ}$ and is degraded to $2^{\circ} \times 2.5^{\circ}$ for input into our simulations. The GEOS-Chem global mercury simulation was described and evaluated in Selin et al. (2007) and Strode et al. (2007), with updates by Selin et al. (2008), Holmes et al. (2010), Soerensen et al. (2010b), and Amos et al. (2012). It couples a three-dimensional atmosphere, a twodimensional mixed layer slab ocean, and a two-dimensional terrestrial reservoir. For consistency with most ground-based observations, we use meteorological years 2009-2011 for analysis after a spin-up period of 4 years.

Three mercury tracers (representing GEM, GOM, and PBM) are simulated in the atmosphere in GEOS-Chem. Models have assumed that $\mathrm{Hg}^{0}$ is oxidized by $\mathrm{OH}$, ozone, and/or halogens (Lei et al., 2013; De Simone et al., 2014; Travnikov and Ilyin, 2009; Durnford et al., 2010; Grant et al., 2014). Some studies suggested the gas-phase reaction with $\mathrm{Br}$ was the most important $\mathrm{Hg}^{0}$ oxidation process globally (Seigneur and Lohman, 2008; Hynes et al., 2009), and here we use $\mathrm{Br}$ as the only oxidant of $\mathrm{Hg}^{0}$ (Holmes et al., 2010; Goodsite et al., 2012). Tropospheric Br fields are archived from a full chemistry GEOS-Chem simulation (Parrella et al., 2012). Models also hypothesize gas- and/or aqueousphase reductions of oxidized $\mathrm{Hg}$ and scale their kinetics to match atmospheric observations (Holmes et al., 2010; Pongprueksa et al., 2011; Selin et al., 2007). However, an accurate determination of potential pathways is lacking (Subir et al., 2011, 2012), and their atmospheric relevance is unknown (Gårdfeldt and Jonsson, 2003). Thus, we do not include atmospheric reduction of oxidized $\mathrm{Hg}$ in our simulations.

\subsection{Emission inversion: reference emissions}

For our reference emissions, we use parameterizations in GEOS-Chem with improvements from recent literature. As shown in Table 2, the global mercury emission is estimated as $6.0 \mathrm{Gg} \mathrm{yr}^{-1}$, with an uncertainty range of $0.4-12.2 \mathrm{Gg} \mathrm{yr}^{-1}$. Mercury released via natural processes is assumed to be entirely $\mathrm{Hg}^{0}$ (Stein et al., 1996), while a small fraction of anthropogenic mercury is in oxidized forms. Anthropogenic emission is unidirectional, but air-surface exchange is bidirectional (emission and deposition) (Xu et al., 1999; Gustin et al., 2008). A positive net emission from a surface means it is a net source of $\mathrm{Hg}^{0}$, whereas a negative value means it

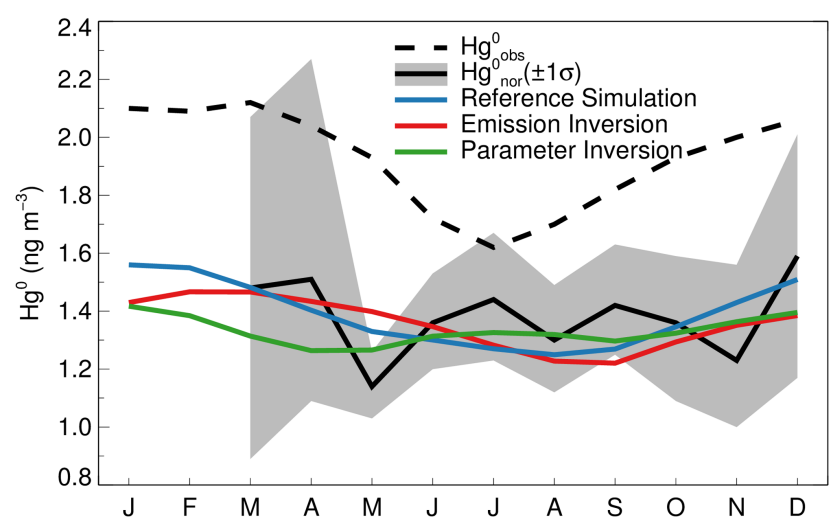

Figure 2. Observed and modeled monthly $\mathrm{Hg}^{0}$ concentrations over the North Atlantic Ocean. The observational data and related references are given in the Supplement. $\mathrm{Hg}_{\text {obs }}^{0}$ are the concentrations observed from 19 ship cruises during 1990-2009, whereas $\mathrm{Hg}_{\text {nor }}^{0}$ are the concentrations normalized to levels consistent with year 2009. The gray shaded region shows the $1 \sigma$ error of $\mathrm{Hg}_{\text {nor }}^{0}$, which is composed of the observational error, mismatch error, and regression error.

is a net sink. We describe below our reference emissions for individual sources.

\subsubsection{Anthropogenic sources}

We use the anthropogenic emission inventory based on activity data for year 2010, developed by AMAP/UNEP (2013). As shown in Table 2, the total anthropogenic emission is $1960 \mathrm{Mg} \mathrm{yr}^{-1}$, with an uncertainty range of 1010 $4070 \mathrm{Mg} \mathrm{yr}^{-1}$ (AMAP/UNEP, 2013). We do not optimize oxidized mercury emissions (accounting for 19\% of the total anthropogenic sources) because this form has a short atmospheric lifetime (days to weeks) and may not significantly contribute to observed TGM concentrations. The geospatial distribution for emissions from contaminated sites (Kocman et al., 2013) is not available for this inventory, and we distribute this small source $\left(80 \mathrm{Mg} \mathrm{yr}^{-1}\right)$ based on the locations of mercury mines (Selin et al., 2007). We do not consider in-plume reduction of oxidized $\mathrm{Hg}$ emitted from coal-fired power plants (Y. Zhang, et al., 2012). About $50 \%$ of global emissions are from Asia (defined as $65-146^{\circ} \mathrm{E}, 9^{\circ} \mathrm{S}-60^{\circ} \mathrm{N}$ ), and a small fraction are from Europe and North America (together $<10 \%$ ). For other regions like Africa and South America, there is no effective observational site to constrain emissions (Fig. 1). Thus, only anthropogenic emissions from Asia are optimized in the inversion, but we still include other regions' anthropogenic emissions in the GEOS-Chem simulations. 
Table 2. Global mercury emissions into the atmosphere $\left(\mathrm{Mg} \mathrm{yr}^{-1}\right) .^{\mathrm{a}}$

\begin{tabular}{|c|c|c|c|}
\hline Source & $\begin{array}{l}\text { Included in } \\
\text { inversion? }\end{array}$ & Reference emission & Optimized emission \\
\hline Anthropogenic ${ }^{\mathrm{c}}$ & & $1960(420-3510)$ & $2250(1150-3360)$ \\
\hline Asia & $\mathrm{Y}$ & $770 \pm 390$ & $1060 \pm 110$ \\
\hline Other regions & $\mathrm{N}$ & 760 & 760 \\
\hline Contaminated sites & $\mathrm{N}$ & $80(70-100)$ & $80(70-100)$ \\
\hline Oxidized $\mathrm{Hg}$ & $\mathrm{N}$ & 350 & 350 \\
\hline Net ocean & & $2990(470-5510)$ & $3160(1160-5160)$ \\
\hline Net NH ocean & $\mathrm{Y}$ & $1230 \pm 630$ & $1670 \pm 530$ \\
\hline Net SH ocean & $\mathrm{Y}$ & $1760 \pm 880$ & $1490 \pm 680$ \\
\hline Net terrestrial $^{\mathrm{d}}$ & & $1070(-510$ to 3130$)$ & $340(-590$ to 1750$)$ \\
\hline Soil & $\mathrm{Y}$ & $1680 \pm 840$ & $860 \pm 440$ \\
\hline Prompt re-emission & $\mathrm{N}$ & 520 & 500 \\
\hline $\mathrm{Hg}^{0}$ dry deposition & $\mathrm{N}$ & -1430 & -1320 \\
\hline Geogenic & $\mathrm{N}$ & $90(60-600)$ & $90(60-600)$ \\
\hline Biomass burning & $\mathrm{N}$ & 210 & 210 \\
\hline TOTAL ${ }^{\mathrm{e}}$ & & $6020(380-12150)$ & $5750(1720-10270)$ \\
\hline
\end{tabular}

a Flux values in parentheses indicate estimated uncertainty ranges. For sources included in the inversion, "average $\pm S D$ " is shown. The uncertainty ranges of contaminated sites and geogenic emissions are from AMAP/UNEP (2013) and Mason (2009), respectively. If the uncertainty range of a source is not available, we assume that its SD is a half of its best estimate. ${ }^{\mathrm{b}}$ Only selected mercury emission sources are included in the inversion, see Sect. 2.3.4. ${ }^{\mathrm{c}}$ Oxidized $\mathrm{Hg}$ emissions from anthropogenic sources are not included in the inversion. "Asia" and "Other regions" (except Asia) refer to emissions of $\mathrm{Hg}^{0} .{ }^{\mathrm{d}}$ Because air-terrestrial interactions are bi-directional, we assume that uncertainties of prompt re-emission and $\mathrm{Hg}^{0}$ deposition have been covered by that of soil emission. ${ }^{\mathrm{e}}$ Total mercury emissions are the sum of anthropogenic, net ocean, and net terrestrial emissions.

\subsubsection{Ocean}

The mixed layer (ML) slab ocean model in GEOS-Chem is described in Soerensen et al. (2010b). Net $\mathrm{Hg}^{0}$ emission from ocean surfaces is determined by the supersaturation of $\mathrm{Hg}_{\mathrm{aq}}^{0}$ in the ML relative to the atmosphere and the air-sea exchange rate. $\mathrm{Hg}_{\mathrm{aq}}^{0}$ in the ML is mainly produced by the net photolytic and biotic reduction of $\mathrm{Hg}_{\mathrm{aq}}^{2+}$. Atmospheric deposition accounts for most $\mathrm{Hg}_{\mathrm{aq}}^{2+}$ inputs into the ML, but subsurface waters also contribute a considerable fraction. The ML interacts with subsurface waters through entrainment/detrainment of the ML and wind-driven Ekman pumping.

We improve several parameterizations in GEOS-Chem based on recent findings. (1) Basin-specific subsurface water mercury concentrations are updated according to new measurements (Lamborg et al., 2012; Munson, 2014), as shown in the Supplement, Fig. S4. (2) Soerensen et al. (2010b) used the Wilke-Chang method for estimating the $\mathrm{Hg}_{\mathrm{aq}}^{0}$ diffusion coefficient $\left(D_{\mathrm{Hg}}\right)$ (Wilke and Chang, 1955), but this estimate was believed to be too high (Loux, 2004). We adopt a revised $D_{\mathrm{Hg}}$ derived by molecular dynamics (MD) simulation (Kuss et al., 2009). As shown in the Supplement, Fig. S5, compared to the Wilke-Chang method, the MD simulation obtains a $D_{\mathrm{Hg}}$ that agrees much better with laboratory results (Kuss, 2014). (3) Particulate mercury $\left(\mathrm{Hg}_{\mathrm{aq}}^{\mathrm{P}}\right)$ sinking from the ML is estimated by linking the organic carbon export (biological pump) and $\mathrm{Hg}_{\mathrm{aq}}^{\mathrm{P}}$ : C ratios. Soerensen et al. (2010b) used the model of Antia et al. (2001) for estimating carbon export fluxes, giving a global total of $23 \mathrm{Gt} \mathrm{C} \mathrm{yr}^{-1}$. However, this estimate is mainly based on the flux measurement data from much deeper depths and may not well represent carbon export from the ML. Different models suggest global carbon export fluxes ranging from 5 to $20 \mathrm{GtC} \mathrm{yr}^{-1}$ with a best estimate of $11 \mathrm{GtC} \mathrm{yr}^{-1}$ (Sanders et al., 2014; Henson et al., 2011). Thus, we multiply carbon export fluxes in GEOS-Chem by a factor of $0.47\left(11 \mathrm{Gt} \mathrm{Cyr}^{-1} / 23 \mathrm{Gt} \mathrm{C} \mathrm{yr}^{-1}\right)$ to match this best estimate.

Net global ocean emission of $2990 \mathrm{Mg} \mathrm{yr}^{-1}$ from the improved GEOS-Chem (considered as reference emission, shown in Table 2) compares favorably with best estimates of $2680 \mathrm{Mg} \mathrm{yr}^{-1}$ using a bottom-up approach (Pirrone et al., 2010; Mason, 2009). Due to their different seasonal characteristics, we divide the global ocean into the NH (Northern Hemisphere) and SH (Southern Hemisphere) oceans and optimize their emissions separately.

\subsubsection{Terrestrial ecosystem}

Although atmosphere-terrestrial $\mathrm{Hg}^{0}$ exchange is bidirectional, only recently developed exchange models have coupled deposition (downward) and emission (upward) fluxes and dynamically estimated net fluxes by gradients be- 
tween air $\mathrm{Hg}^{0}$ and "compensation points" inferred from surface characteristics (Bash, 2010; Bash et al., 2007). Because their complex parameterizations lack field data for verification (X. Wang et al., 2014), such exchange models have not been incorporated into current global CTMs. As described in Selin et al. (2008) and Holmes et al. (2010), GEOS-Chem treats emission and deposition fluxes of $\mathrm{Hg}^{0}$ separately. Only dry deposition is considered for $\mathrm{Hg}^{0}$ due to its low Henry's law constant (Lin and Pehkonen, 1999). Net emission from terrestrial surfaces $\left(E_{\text {net }}\right)$ represents the sum of these processes: volatilization from soil ( $\left.E_{\text {soil }}\right)$, prompt re-emission of deposited $\mathrm{Hg}\left(E_{\mathrm{pr}}\right)$, geogenic activity $\left(E_{\mathrm{gg}}\right)$, biomass burning $\left(E_{\mathrm{bb}}\right)$, and dry deposition to surfaces $\left(E_{\mathrm{ddHg}^{0}}\right)$.

$E_{\mathrm{net}}=E_{\mathrm{soil}}+E_{\mathrm{pr}}+E_{\mathrm{gg}}+E_{\mathrm{bb}}-E_{\mathrm{ddHg}^{0}}$

Soil emission $\left(E_{\text {soil }}\right)$ is specified as a function of solar radiation and soil $\mathrm{Hg}$ concentration:

$E_{\text {soil }}\left(\mathrm{ng} \mathrm{m}^{-2} \mathrm{~h}^{-1}\right)=\beta C_{\text {soil }} \exp \left(1.1 \times 10^{-3} \times R_{\mathrm{g}}\right)$,

where $C_{\text {soil }}$ is soil $\mathrm{Hg}$ concentration $\left(\mathrm{ng} \mathrm{g}^{-1}\right)$ and $R_{\mathrm{g}}$ is the solar radiation flux at the ground $\left(\mathrm{W} \mathrm{m}^{-2}\right)$. GEOS-Chem assumes a global average soil concentration of $43 \mathrm{ng} \mathrm{g}^{-1}$ for preindustrial conditions and derives its spatial distribution from the local equilibrium between emission and deposition. The scaling factor $\beta\left(1.2 \times 10^{-2} \mathrm{~g} \mathrm{~m}^{-2} \mathrm{~h}^{-1}\right)$ is obtained from the global mass balance of the preindustrial simulation. Selin et al. (2008) assumed that present-day soil mercury reservoir and emission have both increased by $15 \%$ compared to the preindustrial period and distributed this global average increase according to the present-day deposition pattern of anthropogenic emission. However, by linking soil mercury with organic carbon pools, Smith-Downey et al. (2010) estimated that present-day $\mathrm{Hg}$ storage in organic soils has increased by $20 \%$ while soil emission by $190 \%$. Mason and Sheu (2002) suggested doubled soil emissions compared to preindustrial times. Thus, following Smith-Downey et al. (2010), we assume a $190 \%$ global increase in the present day, and distribute this increase according to the anthropogenic emission deposition pattern. The present-day reference soil emission is calculated to be $1680 \mathrm{Mg} \mathrm{yr}^{-1}$.

An additional $520 \mathrm{Mg} \mathrm{yr}^{-1}$ is emitted from the soil, vegetation, and snow $\left(E_{\mathrm{pr}}\right)$ through rapid photoreduction of recently deposited oxidized $\mathrm{Hg}$ (Fisher et al., 2012). Geogenic emission $\left(E_{\mathrm{gg}}\right)$ is set as $90 \mathrm{Mg} \mathrm{yr}^{-1}$, consistent with its best bottom-up estimate (Mason, 2009; Bagnato et al., 2014). Biomass burning $\left(E_{\mathrm{bb}}\right)$ of $210 \mathrm{Mg} \mathrm{yr}^{-1}$ is estimated using the Global Fire Emissions Database version 3 of CO (van der Werf et al., 2010) and a $\mathrm{Hg}$ : CO ratio of $100 \mathrm{nmol} \mathrm{mol}^{-1}$ (Holmes et al., 2010). This amount falls at the lower end of bottom-up estimates (Friedli et al., 2009). Dry deposition of $\mathrm{Hg}^{0}$ is estimated using a resistance-in-series scheme (Wesely, 1989) and has a downward flux of $1430 \mathrm{Mg} \mathrm{yr}^{-1}$. Using Eq. (1), net emission of $\mathrm{Hg}^{0}$ from terrestrial surfaces is calculated to be $1070 \mathrm{Mg} \mathrm{yr}^{-1}$ in GEOS-Chem (Table 2), at the lower end of the bottom-up estimates (1140-5280 $\mathrm{Mg} \mathrm{yr}^{-1}$ ) (Mason, 2009; Pirrone et al., 2010) and also lower than $1910 \mathrm{Mg} \mathrm{yr}^{-1}$ by Kikuchi et al. (2013) using a different empirical mechanism (Lin et al., 2010).

\subsubsection{Sources included in emission inversion}

Because of limitations in both observations and the CTM, only anthropogenic emission from Asia, ocean evasion (separated into the $\mathrm{NH}$ and $\mathrm{SH}$ ), and soil emission are optimized in the emission inversion (see Table 2). The remaining sources are still included in the simulation but not inverted because they are too diffusely distributed, their magnitude is small, and/or observations are not sensitive to them (Chen and Prinn, 2006). The seasonal sources (the NH ocean, $\mathrm{SH}$ ocean, and soil) usually have strong spatiotemporal variations and the inversion optimizes their monthly magnitudes and uncertainties. For the aseasonal Asian anthropogenic emission, the inversion optimizes its annual magnitude and uncertainty.

\subsection{Bayesian inversion method}

We use a Bayesian method to invert emissions and parameters with a weighted least-squares technique (Ulrych et al., 2001). The unknowns (correction factors for reference emissions and parameters) are contained in a state vector $\boldsymbol{x}$ and their a priori errors (uncertainties in reference emissions and parameters) in a matrix $\mathbf{P}$. In the emission inversion, as we include one aseasonal source (Asian anthropogenic emission) and three monthly sources (the NH ocean, SH ocean, and soil), the vector $\boldsymbol{x}$ contains 37 elements. $\mathbf{P}$ is a $37 \times 37$ diagonal matrix with each diagonal element equal to the square of $1 \sigma$ a priori error of the corresponding element in $\boldsymbol{x}$ (see Sect. 2.6.1).

Our inversion method assumes a linear relationship between the observation vector $\boldsymbol{y}^{\text {obs }}$ and $\boldsymbol{x}$, as shown in the measurement equation:

$\boldsymbol{y}^{\mathrm{obs}}=\boldsymbol{y}^{\mathrm{ref}}+\mathbf{H} \boldsymbol{x}+\boldsymbol{\varepsilon}$,

where $\boldsymbol{y}^{\text {ref }}$ contains monthly $\mathrm{Hg}^{0}$ concentrations modeled by GEOS-Chem using the reference emissions and parameters. The vectors $\boldsymbol{y}^{\mathrm{obs}}$ and $\boldsymbol{y}^{\text {ref }}$ both have 12 (number of months per year) $\times 27$ (number of observational sites $)=324$ elements. $\boldsymbol{\varepsilon}$ represents the model and observational errors which will be discussed in detail in Sect. 2.6.

The state vector $\boldsymbol{x}$ is related to monthly $\mathrm{Hg}^{0}$ concentrations by the sensitivity matrix $\mathbf{H}$, in which the elements are written as

$\mathbf{h}_{i j}=\frac{\boldsymbol{y}_{i}-\boldsymbol{y}_{i}^{\mathrm{ref}}}{\boldsymbol{x}_{j}-\boldsymbol{x}_{j}^{\mathrm{ref}}} \approx \frac{\partial \boldsymbol{y}_{i}}{\partial \boldsymbol{x}_{j}}$,

where $\mathrm{i}$ and $\mathrm{j}$ are indices for the observational and state vectors, respectively. $\mathbf{H}$ describes how monthly $\mathrm{Hg}^{0}$ concentrations at different observational sites respond to changes in the 
state vector $\boldsymbol{x}$ (for examples see the Supplement, Fig. S6). The GEOS-Chem CTM acts as a mathematical operator relating the emissions/parameters to monthly $\mathrm{Hg}^{0}$ concentrations. For the emission inversion, sensitivities for the seasonal and aseasonal sources are generated by two different types of simulations. The aseasonal Asian anthropogenic emission is perturbed above the reference level by $50 \%$, and we run the GEOS-Chem CTM until steady state is reached. For the seasonal sources (e.g., the NH ocean emission from March), a 1-month pulse of $\mathrm{Hg}^{0}$ is emitted, and we track modeled $\mathrm{Hg}^{0}$ concentrations by GEOS-Chem for the next 3 years. After this, we assume that the perturbed concentrations at all observational sites will exponentially decrease (Saikawa et al., 2012).

The objective function $\mathbf{J}$ with respect to $\boldsymbol{x}$ is

$$
\begin{aligned}
\mathbf{J}(\boldsymbol{x})= & \boldsymbol{x}^{T} \mathbf{P}^{-1} \boldsymbol{x}+\left(\mathbf{H} \boldsymbol{x}-\boldsymbol{y}^{\mathrm{obs}}+\boldsymbol{y}^{\mathrm{ref}}\right)^{T} \\
& \mathbf{R}^{-1}\left(\mathbf{H} \boldsymbol{x}-\boldsymbol{y}^{\mathrm{obs}}+\boldsymbol{y}^{\mathrm{ref}}\right),
\end{aligned}
$$

where $\mathbf{R}$, a diagonal $324 \times 324$ matrix, represents errors related to observations and the CTM and will be described in detail in Sect. 2.6. By minimizing $\mathbf{J}$, we obtain the expression for the optimal estimate of the state $\boldsymbol{x}$ :

$\boldsymbol{x}=\left(\mathbf{H}^{T} \mathbf{R}^{-1} \mathbf{H}+\mathbf{P}^{-1}\right)^{-1} \mathbf{H}^{T} \mathbf{R}^{-1}\left(\boldsymbol{y}^{\mathrm{obs}}-\boldsymbol{y}^{\mathrm{ref}}\right)$,

$\mathbf{Q}=\left(\mathbf{H}^{T} \mathbf{R}^{-1} \mathbf{H}+\mathbf{P}^{-1}\right)^{-1}$,

where the matrix $\mathbf{Q}$ contains the a posteriori errors of $\boldsymbol{x}$. The size of $\mathbf{Q}$ is the same as the matrix $\mathbf{P}$. Each diagonal element in $\mathbf{Q}$ is the square of $1 \sigma$ a posteriori error of the corresponding element in $\boldsymbol{x}$. A detailed mathematical derivation of the above equations can be found in Wunsch (2006). As shown in Eqs. (6) and (7), several vectors and matrices need to be calculated during the optimization procedure, including the observational vector $\boldsymbol{y}^{\text {obs }}$ and its error matrix $\mathbf{R}$, the error matrix $\mathbf{P}$ of the a priori state, the sensitivity matrix $\mathbf{H}$, and the vector $\boldsymbol{y}^{\mathrm{ref}}$ which is obtained from the reference simulation of the GEOS-Chem CTM.

\subsection{Parameter inversion}

As described in Sect. 3.2.1, based on results of ocean evasion in our emission inversion and sensitivity tests of model parameters, we identify two ocean parameters in GEOS-Chem for improvement: the rate constant of dark oxidation of $\mathrm{Hg}_{\mathrm{aq}}^{0}$ (denoted as $K_{\mathrm{OX} 2}$, following notations in Soerensen et al., 2010b) and the partition coefficient between $\mathrm{Hg}_{\mathrm{aq}}^{2+}$ and $\mathrm{Hg}_{\mathrm{aq}}^{\mathrm{P}}$ (denoted as $K_{D}$ ). For simplicity they are expressed in decimal logarithms $\left(-\log K_{\mathrm{OX} 2}\right.$ and $\left.\log K_{D}\right)$.

$\mathrm{A}-\log K_{\mathrm{OX} 2}\left(\mathrm{~s}^{-1}\right)$ of 7.0 is specified in GEOS-Chem (Soerensen et al., 2010b). From a survey of laboratory studies (see details in the Supplement) (Amyot et al., 1997; Lalonde et al., 2001, 2004; Qureshi et al., 2010), we suggest that this value is too low and that a more appropriate range of $-\log$ $K_{\mathrm{OX} 2}$ is 4.0-6.0. The chemical mechanisms for dark oxidation of $\mathrm{Hg}_{\mathrm{aq}}^{0}$ remain unclear. $\mathrm{OH}$ generated from photochemically produced $\mathrm{H}_{2} \mathrm{O}_{2}$ via the Fenton reaction may oxidize $\mathrm{Hg}_{\mathrm{aq}}^{0}$ in dark conditions (Zhang and Lindberg, 2001; Zepp et al., 1992). Light irradiation before a dark period is needed, and dark oxidation kinetics depend on intensity and duration of light (Qureshi et al., 2010; Batrakova et al., 2014). Future work could include a more mechanistic representation of this process as laboratory studies become available.

$K_{D}\left(=C_{s} / C_{d} C_{\mathrm{SPM}}\right)$ describes the affinity of aqueous $\mathrm{Hg}^{2+}$ for suspended particulate matter (SPM), where $C_{s}$, $C_{d}$, and $C_{\mathrm{SPM}}$ are the concentrations of $\mathrm{Hg}_{\mathrm{aq}}^{\mathrm{P}}, \mathrm{Hg}_{\mathrm{aq}}^{2+}$, and SPM, respectively. GEOS-Chem uses a $\log K_{D}\left(\mathrm{~L} \mathrm{~kg}^{-1}\right)$ of 5.5 based on measurements in the North Pacific and North Atlantic oceans (Mason and Fitzgerald, 1993; Mason et al., 1998).

In the parameter inversion, we attempt to constrain these two ocean model parameters using the Bayesian approach described in Sect. 2.4. For consistency with sources in the emission inversion, two other parameters are included, i.e., emission ratios for soil $\left(\mathrm{ER}_{\text {Soil }}\right)$ and Asian anthropogenic sources $\left(E_{\text {Asia }}\right)$. It is noted that the emission inversion and parameter inversion are carried out separately. Because the responses of $\mathrm{Hg}^{0}$ concentrations to changes in ocean parameters are nonlinear, as shown in the Supplement Fig. S7, we use a two-step iterative inversion method (Prinn et al., 2011). At each iteration step, the sensitivity matrix $\mathbf{H}$ is estimated by linearizing the nonlinear function around the current parameter estimate. In the parameter inversion, the state vector $x$ contains four elements (corresponding to the four parameters), and $\mathbf{P}$ and $\mathbf{Q}$ are $4 \times 4$ matrices.

\subsection{Error representation}

Successful estimation of $\boldsymbol{x}$ (Eq. 6) and its uncertainty $\mathbf{Q}$ (Eq. 7) depends on reasonable representations of all relevant errors, including the a priori errors associated with reference emissions/parameters (contained in $\mathbf{P}$ ) and errors related to $\mathrm{Hg}^{0}$ observations and the CTM (contained in $\mathbf{R}$ ). $\mathbf{R}$ consists of three parts: observational errors, model-observation mismatch errors, and model errors.

\subsubsection{Errors in reference emission and parameters}

For the emission inversion, we set the $1 \sigma$ errors in reference emissions as $50 \%$ in order to match uncertainties in their estimates using bottom-up approaches (see Table 2). For example, the reference emissions and $1 \sigma$ errors for the $\mathrm{NH}$ and SH oceans are $1230 \pm 630$ and $1760 \pm 880 \mathrm{Mg} \mathrm{yr}^{-1}$, respectively. The uncertainty range of reference emission from the global ocean is estimated as $470-5510 \mathrm{Mg} \mathrm{yr}^{-1}$, comparing very well with $780-5280 \mathrm{Mg} \mathrm{yr}^{-1}$ from bottom-up estimates (Mason, 2009; Pirrone et al., 2010). For the parameter inversion, the a priori estimates of two ocean model parameters 
are taken from literature reviews (Batrakova et al., 2014): $-\log K_{\mathrm{OX} 2}(5.0 \pm 1.0)$ and $\log K_{D}(5.3 \pm 0.4)$. The a priori uncertainties of $\mathrm{ER}_{\mathrm{Soil}}$ and $\mathrm{ER}_{\mathrm{Asia}}$ are chosen as $50 \%$, the same as in the emission inversion.

\subsubsection{Observational errors}

Observational errors for ground-based sites determine their relative importance in deriving the optimized state. As shown in Eq. (8), the total observational errors $\left(\sigma_{\mathrm{TOT}}\right)$ contain instrumental precision $\left(\sigma_{\mathrm{IP}}\right)$, intercomparison $\left(\sigma_{\mathrm{IC}}\right)$, and sampling frequency errors $\left(\sigma_{\mathrm{SF}}\right)$ (Rigby et al., 2012; Chen and Prinn, 2006).

$\sigma_{\mathrm{TOT}}=\sqrt{\sigma_{\mathrm{IP}}^{2}+\sigma_{\mathrm{IC}}^{2}+\sigma_{\mathrm{SF}}^{2}}$

The instrumental precision $\left(\sigma_{\mathrm{IP}}\right)$ of high-frequency $\mathrm{Hg}^{0}$ measurements using the Tekran instrument is $\sim 2 \%$ (Poissant et al., 2005). Here an intercomparison error $\left(\sigma_{\text {IC }}\right)$ is used to represent the comparability of $\mathrm{Hg}^{0}$ concentrations measured by different research groups using the Tekran instrument. In principle, it includes several inaccuracies during the measurement process (e.g., the instrument's flow control and the permeation source rate for the automated calibration) and also arises from the different data management and quality control protocols taken by different research groups (Steffen et al., 2012). Its value has been assessed during several field intercomparisons (Temme et al., 2006; Aspmo et al., 2005; Munthe et al., 2001; Ebinghaus et al., 1999; Schroeder et al., 1995). $\mathrm{Hg}^{0}$ concentrations measured by different groups have a relative SD of reproducibility of 1-9\%, and we choose a generous uniform intercomparison error of $10 \%$. Sampling frequency error $\left(\sigma_{\mathrm{SF}}\right)$ reflects the ability of each site to capture the overall variability of $\mathrm{Hg}^{0}$ concentration in 1 month and is calculated as the monthly SD divided by the square root of the number of valid hourly data points in this month (Rigby et al., 2012). Table 1 shows observational errors at each site, averaged over 2009-2011. The total observational errors are dominated by intercomparison errors. The other two types of errors have small contributions.

\subsubsection{Model-observation mismatch errors}

The mismatch error $\left(\sigma_{\mathrm{MM}}\right)$ exists because an observation is made at a single point in space, but its corresponding grid box in model represents a large volume of air. We estimate $\sigma_{\mathrm{MM}}$ as the $\mathrm{SD}$ of monthly $\mathrm{Hg}^{0}$ concentrations in the eight surrounding grid boxes (at the same vertical layer) from the reference simulation (Chen and Prinn, 2006). As shown in Table $1, \sigma_{\mathrm{MM}}$ values are larger over strongly emitting continental areas (e.g., SGR and WLG) and smaller over remote marine areas (e.g., CPT and AMS).

\subsubsection{Model errors}

All existing CTMs including GEOS-Chem are imperfect, due to both errors in meteorological data driving the CTMs and errors induced by their parameterizations of physical and chemical processes. The former type of model errors is termed "forcing errors" and the latter "process errors" (Locatelli et al., 2013). Physical processes consist of horizontal/vertical resolution, advection/convection, turbulence, planetary boundary layer mixing, etc. The CTM for $\mathrm{Hg}$ is subject to large process errors due to highly uncertain atmospheric chemistry. Recent studies have shown that $\mathrm{Br}$ concentration may be significantly underestimated in GEOSChem (Parrella et al., 2012; Gratz et al., 2015) and that current $\mathrm{Br}$-initiated oxidation mechanisms are incomplete in describing all possible radical reactions (Dibble et al., 2012; F. Wang, et al., 2014). In order to provide a preliminary assessment of the effect of Br oxidation chemistry on our inversion, we perform an additional parameter inversion including six new elements in the state vector $\boldsymbol{x}$, and each of them represents $\mathrm{Br}$ columns in a $30^{\circ}$ latitudinal band (see results in Sect. 3.3 and Fig. S8 in the Supplement).

Quantifying model errors requires incorporating many CTMs which are driven by different meteorology and which contain different parameterizations (Prinn, 2000). MultiCTM intercomparison studies have been performed for $\mathrm{CO}_{2}$ and $\mathrm{CH}_{4}$ (Gurney et al., 2002; Baker et al., 2006; Locatelli et al., 2013), suggesting that model errors can impact inverted emissions. Few other global CTMs exist for $\mathrm{Hg}$ (Bullock et al., 2008, 2009). Due to our inability to quantify model errors using a single CTM, model errors are not incorporated in our inversion, like many other inverse studies (Huang et al., 2008; Xiao et al., 2010; Rigby et al., 2012). As a result, $\mathbf{R}$ in Eq. (5) only includes observational errors and modelobservation mismatch errors.

\section{Results and discussion}

\subsection{Emission inversion: model-observation comparison}

We first test whether the comparison between ground-based $\mathrm{Hg}^{0}$ observations and model outputs improves when using optimized emissions, compared to reference emissions. Figure 3 shows the modeled and observed $\mathrm{Hg}^{0}$ concentrations at all 27 sites. To quantify model performance, we calculate the normalized root mean square error (NRMSE) for each site:

$\mathrm{NRMSE}=\frac{\sqrt{\frac{1}{n} \sum_{i=1}^{n}\left(X_{\mathrm{obs}, i}-X_{\mathrm{mod}, i}\right)^{2}}}{\frac{1}{n} \sum_{i=1}^{n} X_{\mathrm{obs}, i}}$,

where $X_{\mathrm{obs}, i}$ and $X_{\mathrm{mod}, i}$ are the observed and modeled $\mathrm{Hg}^{0}$ concentrations at the $i$ th month ( $n$ in total), respectively. As 

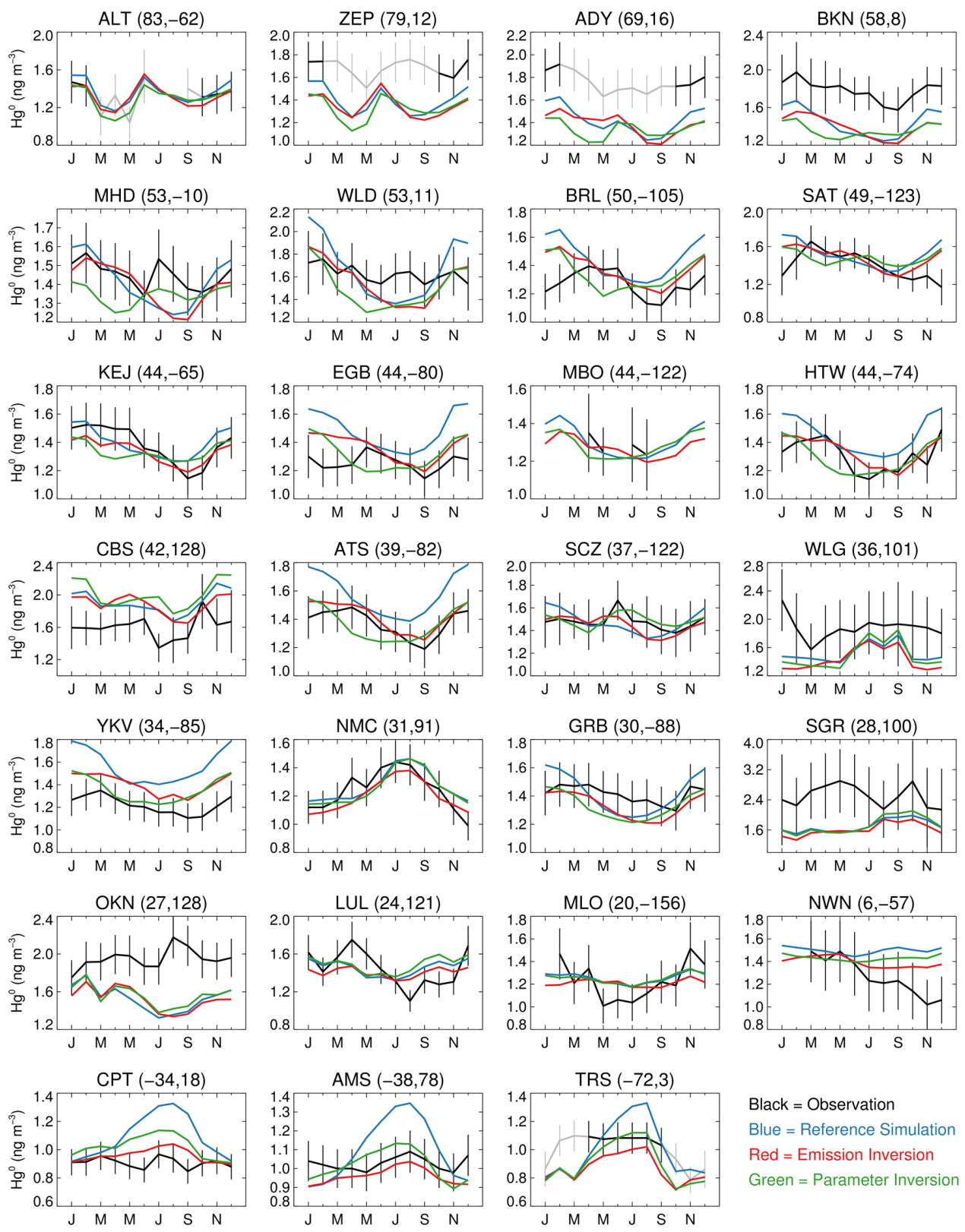

Black = Observation

Blue $=$ Reference Simulation

Red = Emission Inversion

Green $=$ Parameter Inversion

Figure 3. Monthly $\mathrm{Hg}^{0}$ concentrations for all ground-based observational sites. Note different scales on vertical axes. Error bars correspond to the total errors described in Sect. 2.6. The two numbers in parentheses after the name of each site are its latitude and longitude. For polar sites (ALT, ZEP, ADY, and TRS), the gray color shows the observed $\mathrm{Hg}^{0}$ concentrations that are not used in our inversions due to AMDEs, as shown in Sect. 2.1.

shown in Table 1, an average NRMSE of 0.13 is obtained for the emission inversion, smaller than that of 0.16 for the reference simulation, indicating that the emission inversion can better reproduce ground-based observations. While this is a relatively small uncertainty reduction $(-0.03)$, we do not expect better performance for our inversion. This is because errors in $\mathrm{Hg}^{0}$ observations (as described above, and in Table 1) are roughly $13 \%$, which constrain the optimization.
Our inversion brings the average NRMSE within the observation error.

The NRMSEs are not reduced for all 27 sites (see Table 1). For three Nordic sites (ZEP, ADY, and BKN) and four Asia-Pacific sites (WLG, SGR, LUL, and MLO), the NRMSEs increase. $\mathrm{Hg}^{0}$ concentrations are $\sim 1.8 \mathrm{ng} \mathrm{m}^{-3}$ at the three Nordic sites, higher than the modeled values (Fig. 3) from both reference simulation and emission inversion, and also higher than those measured at many background sites 
in Europe (Ebinghaus et al., 2011; Kentisbeer et al., 2014; Weigelt et al., 2013). Part of the differences may be explained by a positive bias in the instrumentation of these Nordic observations when compared to other laboratories (Temme et al., 2006). It is also possible that GEOS-Chem cannot sufficiently capture local meteorology and/or emissions at these sites. For the Asia-Pacific sites, the reference simulation underestimates $\mathrm{Hg}^{0}$ at SGR $(-32 \%$, calculated as $\left(\mathbf{y}^{\mathrm{ref}} / \mathbf{y}^{\mathrm{obs}}-1\right) \times 100 \%$, hereinafter the same $)$ and WLG $(-19 \%)$ and predicts comparable values at MLO (+2\%) and LUL $(+0 \%)$. Such discrepancies likely arise from unknown intercomparison errors and are influenced by local emission and meteorology factors not captured by the CTM (Fu et al., 2012b; Wan et al., 2009). These sites are operated by three different laboratories but, to the best of our knowledge, no field intercomparisons have been conducted among these laboratories.

Figure 4 compares monthly $\mathrm{Hg}^{0}$ observations with model simulations for sites aggregated into four regions: AsiaPacific, North America, Europe, and Southern Hemisphere. The emission inversion significantly improves the comparison for the SH sites (CPT, AMS, and TRS, see Table 1). In the reference simulation, $\mathrm{Hg}^{0}$ concentrations at the $\mathrm{SH}$ sites vary seasonally, with a high in austral winter $\left(\sim 1.3 \mathrm{ng} \mathrm{m}^{-3}\right)$ and a low in austral summer $\left(\sim 0.9 \mathrm{ng} \mathrm{m}^{-3}\right)$. However, observed $\mathrm{Hg}^{0}$ shows little seasonal variation with monthly concentrations of $\sim 1.0 \mathrm{ng} \mathrm{m}^{-3}$. The emission inversion reduces the $\mathrm{Hg}^{0}$ concentration in austral winter and fits the observations much better (the average NRMSE decreases from 0.19 to 0.10 ). As shown in Fig. 3, all three SH sites show improvement after optimization.

The emission inversion also improves the comparison for sites in North America (the average NRMSE decreases from 0.13 to 0.08$). \mathrm{Hg}^{0}$ data at a total of 11 sites are available, including five coastal sites (ALT, SAT, KEJ, SCZ, and GRB), five inland sites (BRL, EGB, HTW, ATS, and $\mathrm{YKV}$ ), and one mountaintop site (MBO) (see Fig. 1 and Table 1). $\mathrm{Hg}^{0}$ at the coastal and inland sites are observed to be $1.41 \pm 0.04$ and $1.29 \pm 0.06 \mathrm{ng} \mathrm{m}^{-3}$, respectively. This coastal-inland difference in observation is consistent with results of Cheng et al. (2014), who found that air masses from open ocean at the site KEJ had $0.06 \mathrm{ng} \mathrm{m}^{-3}$ higher $\mathrm{Hg}^{0}$ concentrations than those originating over land. The reference simulation and emission inversion both obtain comparable $\mathrm{Hg}^{0}$ concentrations at the coastal sites $\left(1.43 \pm 0.06\right.$ and $\left.1.38 \pm 0.07 \mathrm{ng} \mathrm{m}^{-3}\right)$. At the inland sites, the emission inversion predicts $\mathrm{Hg}^{0}$ concentrations $\left(1.38 \pm 0.03 \mathrm{ng} \mathrm{m}^{-3}\right)$ closer to observations than the reference simulation $\left(1.50 \pm 0.06 \mathrm{ng} \mathrm{m}^{-3}\right)$.

Over-water $\mathrm{Hg}^{0}$ observations serve as an independent test of the emission inversion. As shown in Fig. $2, \mathrm{Hg}^{0}$ concentrations over the North Atlantic Ocean from both the reference simulation and the emission inversion fall within $1 \sigma$ uncertainty ranges of $\mathrm{Hg}_{\text {nor }}^{0}$. The NRMSEs for the reference simulation and the emission inversion are 0.09 and 0.10 , respec- tively. Thus, using $\mathrm{Hg}^{0}$ emissions constrained by groundbased observations, GEOS-Chem still matches these regional over-water observations.

We additionally test the performance of the inversion by comparison with regional wet deposition data. Since most oxidized $\mathrm{Hg}$ is formed from the oxidation of $\mathrm{Hg}^{0}$, changing $\mathrm{Hg}^{0}$ emissions may have an effect on modeled oxidized $\mathrm{Hg}$ and its subsequent deposition. We compare model results to the observed wet deposition fluxes from NADP/MDN (2012), as shown in the Supplement, Fig. S9. We use the monitoring sites active in 2009-2011 $(n=126)$. Both the reference simulation and the emission inversion fit observations well ( $R \approx 0.7, \mathrm{NRMSE} \approx 0.3$ ). Accordingly, the effect of the inversion on the NADP/MDN (National Atmospheric Deposition Program/Mercury Deposition Program) wet deposition fluxes is insignificant.

\subsection{Emission inversion: optimized emissions}

The annual reference and optimized emissions of mercury are shown in Table 2 . The relationship $\bar{\sigma}=\sqrt{n \sum_{i=1}^{n} \sigma_{t}^{2}}$, where $n=12$ months and $\sigma_{t}$ is monthly error, is used to compute the annual uncertainty for seasonal processes (Chen and Prinn, 2006). The uncertainty of the aseasonal source (annual Asian anthropogenic emission) is obtained directly from Eq. (7). The global optimized mercury emission is $\sim 5.8 \mathrm{Gg} \mathrm{yr}^{-1}$, with an uncertainty range of $1.7-10.3 \mathrm{Gg} \mathrm{yr}^{-1}$. Compared to our reference emission of $\sim 6.0 \mathrm{Gg} \mathrm{yr}^{-1}$ (uncertainty range: $0.4-12.2 \mathrm{Gg} \mathrm{yr}^{-1}$ ), the emission inversion results in a slightly smaller value and also reduces its uncertainty range. The optimized value is smaller than previous estimates of $7.5 \mathrm{Gg} \mathrm{yr}^{-1}$ by Pirrone et al. (2010) using a bottom-up approach. The emission inversion increases emissions from anthropogenic sources and ocean surfaces but decreases those from terrestrial surfaces. The ocean accounts for more than half $(55 \%)$ of the total, while the terrestrial surface contributes only a small fraction $(6 \%)$.

\subsubsection{Ocean}

Net $\mathrm{Hg}^{0}$ evasion from the global ocean is optimized by the emission inversion as $3160 \mathrm{Mg} \mathrm{yr}^{-1}$, with an uncertainty range of $1160-5160 \mathrm{Mg} \mathrm{yr}^{-1}$ (Table 2). The $\mathrm{NH}$ and $\mathrm{SH}$ oceans contribute similar amounts to the total but, on an area basis, evasion from the NH ocean is higher since it is $30 \%$ smaller. We are able to reduce ocean evasion uncertainty from 50 to $40 \%$ by using top-down constraints.

Figure 5 shows the monthly reference and optimized emissions of seasonal sources. We find, for both hemispheres, that the emission inversion generally results in increased ocean emissions in summer and decreased emissions in winter, compared to the reference simulation. As a result, we hypothesize that one or more ocean processes that affect the 

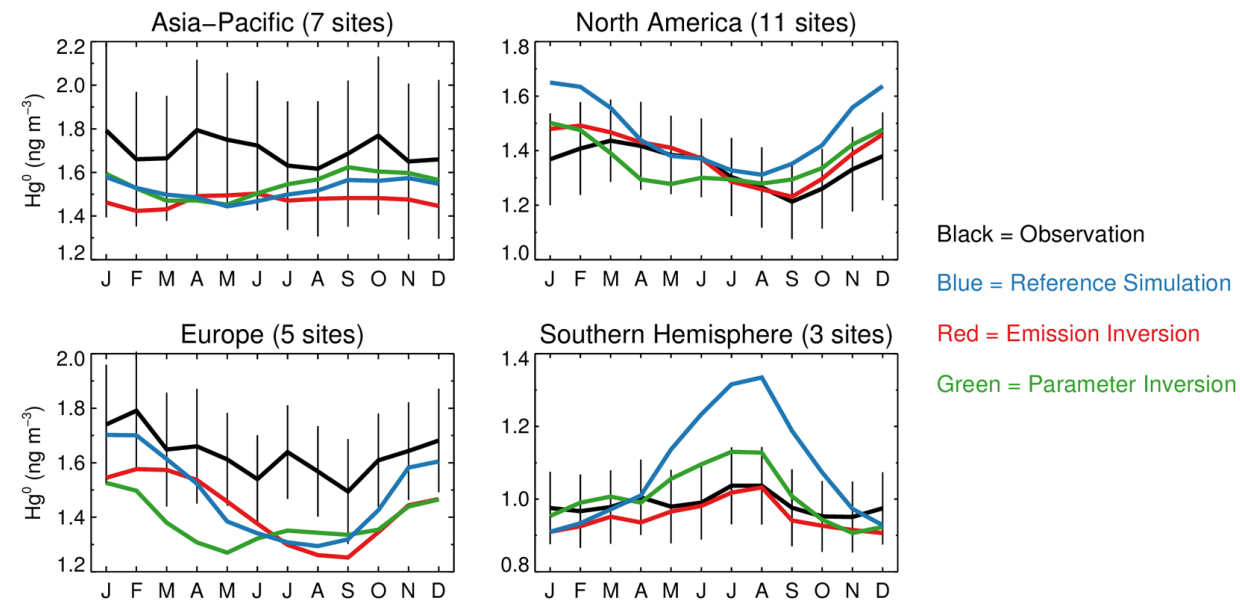

Red $=$ Emission Inversion

Green = Parameter Inversion

Figure 4. Averaged monthly observations and model simulations of $\mathrm{Hg}^{0}$ concentrations for the ground-based observational sites in the four regions (Asia-Pacific: $45^{\circ} \mathrm{E}-140^{\circ} \mathrm{W}, 0-90^{\circ} \mathrm{N}$; North America: $140-45^{\circ} \mathrm{W}, 15-90^{\circ} \mathrm{N}$; Europe: $15^{\circ} \mathrm{W}-45^{\circ} \mathrm{E}, 15-90^{\circ} \mathrm{N}$, and the Southern Hemisphere). Note different scales on vertical axes. $\mathrm{Hg}^{0}$ observations are shown with total errors as described in Sect. 2.6.

seasonal behavior of aqueous mercury and its evasion are not well-represented in GEOS-Chem. We therefore conduct a series of sensitivity studies of model parameters to test their potential effects on the seasonal pattern of ocean emission. We also compare the parameter values used in GEOS-Chem with their possible ranges in a recent review (Batrakova et al., 2014). The tested model parameters in GEOS-Chem include rates of redox chemical reactions and physical processes in the ML and subsurface mercury concentrations affecting physical exchange between the ML and subsurface waters. Through these sensitivity tests and literature review, we identify two processes as candidates for improvement, the rate constant of dark oxidation of $\mathrm{Hg}_{\mathrm{aq}}^{0}\left(K_{\mathrm{OX} 2}\right)$ and the partition coefficient between $\mathrm{Hg}_{\mathrm{aq}}^{2+}$ and $\mathrm{Hg}_{\mathrm{aq}}^{\mathrm{P}}\left(K_{D}\right)$. We optimize these two ocean model parameters in the parameter inversion, as described in Sect. 2.5.

\subsubsection{Terrestrial ecosystem}

As shown in Table 2, the emission inversion reduces soil emissions of $\mathrm{Hg}^{0}$ by about $50 \%$, from $1680 \pm 840$ to $860 \pm 440 \mathrm{Mg} \mathrm{yr}^{-1}$. Using Eq. (1), the optimized net emission flux from terrestrial surfaces $\left(E_{\text {net }}\right)$ is $340 \mathrm{Mg} \mathrm{yr}^{-1}$. If we do not consider geogenic activities $\left(90 \mathrm{Mg} \mathrm{yr}^{-1}\right)$ and biomass burning $\left(210 \mathrm{Mg} \mathrm{yr}^{-1}\right)$, the $E_{\text {net2 }}$ (calculated as $E_{\text {soil }}+E_{\mathrm{pr}}-$ $E_{\mathrm{ddHg}^{0}}$ and representing net emissions from soils/vegetation) is almost zero after optimization. Thus, terrestrial surfaces are neither a net source nor a net sink of $\mathrm{Hg}^{0}$. This is in contrast to bottom-up estimates that the terrestrial surface is a net source of about $2000 \mathrm{Mg} \mathrm{yr}^{-1}$ (Pirrone et al., 2010; Mason, 2009).

Vegetation is now believed to serve as a net sink of atmospheric $\mathrm{Hg}^{0}$ through foliar uptake and sequestration (Gustin et al., 2008; Stamenkovic and Gustin, 2009; X. Wang et al.,
2014). Although its size has not been well quantified, we suggest that this sink is important in global mass balance since litterfall transfers $2400-6000 \mathrm{Mg} \mathrm{Hg} \mathrm{yr}^{-1}$ to terrestrial surfaces (Gustin et al., 2008). Air-soil flux measurements show that $\mathrm{Hg}^{0}$ emissions from background soils generally dominate over dry deposition (Obrist et al., 2014; Edwards and Howard, 2013; Park et al., 2013; Denkenberger et al., 2012; Ericksen et al., 2006). Our result of a smaller soil Hg source is consistent with a study by Obrist et al. (2014), which suggested that $\mathrm{Hg}$ was unlikely to be re-emitted once incorporated into soils and that terrestrial $\mathrm{Hg}$ emission was restricted to surface layers (Demers et al., 2013). Our result is also in agreement with estimates of terrestrial fluxes of southern Africa using $\mathrm{Hg}^{0}$ correlations with ${ }^{222} \mathrm{Rn}$, a radioactive gas of predominantly terrestrial origin (Slemr et al., 2013). Considering that soil is a smaller source while vegetation a sink of $\mathrm{Hg}^{0}$, our result that the terrestrial ecosystem is neither a net source nor a net sink of $\mathrm{Hg}^{0}$ is reasonable, implying that the magnitudes of soil emission and dry deposition of $\mathrm{Hg}^{0}$ (primarily to vegetation) are similar. We evaluate dry deposition fluxes modeled by GEOS-Chem against data in L. Zhang et al. (2012), which estimated fluxes at sites in North America and obtained good agreements with surrogate surface and litterfall measurements (Graydon et al., 2008; Lyman et al., 2007). As shown in the Supplement, Fig. S10, there is no bias in the average dry deposition flux at eight background sites, indicating that $\sim 1400 \mathrm{Mg} \mathrm{yr}^{-1}$ (modeled by GEOS-Chem) may be reasonable estimates for both emission and dry deposition of $\mathrm{Hg}^{0}$.

\subsubsection{Anthropogenic emission from Asia}

Table 3 summarizes Asian emissions of $\mathrm{Hg}^{0}$ (only GEM) estimated by several recent bottom-up emission inventories and modeling studies. These inventories reported Asian anthro- 

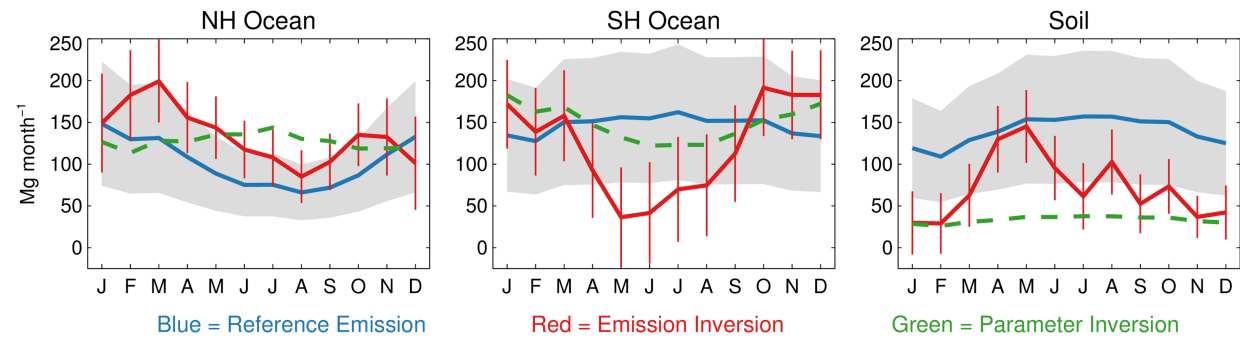

Figure 5. Monthly emissions for the three seasonal sources (NH ocean, SH ocean, and soil) from the reference simulation (blue solid lines), emission inversion (red solid lines), and parameter inversion (green dashed lines). The gray shaded regions and red error bars indicate $1 \sigma$ uncertainties for the reference emissions and emission inversion, respectively.

Table 3. Comparison of Asian $\mathrm{Hg}^{0}$ emissions $\left(\mathrm{Mg} \mathrm{yr}^{-1}\right)$ from recent studies. ${ }^{\mathrm{a}}$

\begin{tabular}{|c|c|c|c|c|c|}
\hline Reference & Base year & Anthropogenic & $\begin{array}{r}\text { Net } \\
\text { terrestrial }^{\mathrm{b}}\end{array}$ & $\begin{array}{r}\text { Net } \\
\text { ocean }\end{array}$ & Total \\
\hline \multicolumn{6}{|c|}{ Emission inventories } \\
\hline Streets et al. $(2009)^{c}$ & 2006 & 800 & & & \\
\hline Streets et al. $(2011)^{\mathrm{c}}$ & 2008 & 700 & & & \\
\hline Muntean et al. (2014) & 2008 & 580 & & & \\
\hline AMAP/UNEP (2013) & 2010 & 770 & & & \\
\hline Rafaj et al. $(2013)^{\mathrm{c}}$ & 2010 & $550-750$ & & & \\
\hline \multicolumn{6}{|c|}{ Other studies } \\
\hline Pan et al. $(2007)^{\mathrm{d}}$ & 1999 & & & 420 & 2270 \\
\hline Shetty et al. $(2008)^{\mathrm{d}}$ & 2001 & & 710 & 120 & \\
\hline Strode et al. (2008) & 2004 & 890-990 & & & $1260-1450$ \\
\hline Fu et al. $(2015)^{\mathrm{e}}$ & 2007-2010 & & & & $1590-1870$ \\
\hline \multicolumn{6}{|l|}{ This study } \\
\hline Reference emission & 2009-2011 & $770 \pm 390$ & 360 & 230 & 1360 \\
\hline Emission inversion & 2009-2011 & $1060 \pm 110$ & 130 & 300 & 1490 \\
\hline $\begin{array}{l}\text { Inversion using different } \\
\text { Asian sites }\end{array}$ & 2009-2011 & $650-1770$ & $0-230$ & $260-300$ & $1180-2030$ \\
\hline
\end{tabular}

\footnotetext{
${ }^{a}$ Here $\mathrm{Hg}^{0}$ only refers to gaseous elemental mercury. ${ }^{\mathrm{b}}$ Net terrestrial and ocean emissions are from the Asian domain. ${ }^{\mathrm{c}}$ Estimated values from tables and figures in the references. ${ }^{\mathrm{d}}$ An east Asian domain is used in these studies. Their terrestrial and ocean surfaces are smaller than those of the Asia domain. ${ }^{\mathrm{e}}$ The Asian domain includes mainland China, southern Asia, Indochinese Peninsula, and central Asia, and does not include ocean surfaces.
}

pogenic emissions ranging from 550 to $800 \mathrm{Mg} \mathrm{yr}^{-1}$. In our model simulations, the reference emission of $770 \mathrm{Mg} \mathrm{yr}^{-1}$ follows AMAP/UNEP (2013). The emission inversion using all 27 sites increases this value to $1060 \pm 110 \mathrm{Mg} \mathrm{yr}^{-1}$. Uncertainty in Asian anthropogenic emission should be larger than that obtained using our inversion method, because emission estimates are sensitive to the Asia-Pacific sites used in the inversion. As discussed above, model performance at several Asia-Pacific sites is affected by unknown intercomparison errors and local emission and meteorological factors not captured by GEOS-Chem. To obtain a more accurate estimate of uncertainty, we perform seven emission inversions, each including only one Asia-Pacific site.

As shown in Table 3, these inversions result in Asian anthropogenic emissions of $\mathrm{Hg}^{0}$ ranging from 650 to
$1770 \mathrm{Mg} \mathrm{yr}^{-1}$. Comparing this range to its bottom-up inventory estimates of $550-800 \mathrm{Mg} \mathrm{yr}^{-1}$, we suggest that it is very likely to be underestimated. We estimate total (anthropogenic + natural + legacy) $\mathrm{Hg}^{0}$ emission in Asia as 1180 $2030 \mathrm{Mg} \mathrm{yr}^{-1}$. Our uncertainty ranges cover those in Strode et al. (2008), which estimated total Asian emission of 1260 $1450 \mathrm{Mg} \mathrm{yr}^{-1}$ with $890-990 \mathrm{Mg} \mathrm{yr}^{-1}$ from anthropogenic sources, by comparing GEOS-Chem to the observed $\mathrm{Hg}$ : $\mathrm{CO}$ ratio at sites OKN and MBO. Pan et al. (2007) assimilated aircraft observations into a regional CTM and estimated total $\mathrm{Hg}^{0}$ emission in east Asia as $2270 \mathrm{Mg} \mathrm{yr}^{-1}$, at the upper end of our range. Fu et al. (2015) obtained a total $\mathrm{Hg}^{0}$ emission in Asia of $1590-1870 \mathrm{Mg} \mathrm{yr}^{-1}$, which compared well with our range, using the $\mathrm{Hg}^{0}: \mathrm{CO}$ and $\mathrm{Hg}^{0}: \mathrm{CO}_{2}$ slopes observed at ground-based sites and inventories of $\mathrm{CO}$ and 
$\mathrm{CO}_{2}$. Shetty et al. (2008) estimated natural terrestrial emission in east Asia was about $710 \mathrm{Mg} \mathrm{yr}^{-1}$, much higher than our $0-230 \mathrm{Mg} \mathrm{yr}^{-1}$ in a larger domain. The difference is due to their larger estimation of vegetation evapotranspiration $\left(630 \mathrm{Mg} \mathrm{yr}^{-1}\right)$.

\subsection{Parameter inversion}

Results of the parameter inversion are presented in Table 4. The a posteriori $K_{\mathrm{OX} 2}$ of $6 \times 10^{-6} \mathrm{~s}^{-1}$ is much larger than its current value $\left(1 \times 10^{-7} \mathrm{~s}^{-1}\right)$ in GEOS-Chem, suggesting that $\mathrm{Hg}_{\mathrm{aq}}^{0}$ dark oxidation in the ML is more important than previously thought. The a posteriori $\log K_{D}$ of 4.2 is lower than seawater values in the literature (Fitzgerald et al., 2007; Batrakova et al., 2014) but agrees with the lower end of freshwater measurements (Amos et al., 2014). We attribute this discrepancy to several simplifying assumptions in GEOSChem. $K_{D}$ is linked to the estimates of SPM concentrations in the ML and organic carbon export. As described above, the amount of organic carbon export is very uncertain (5$20 \mathrm{GtC}^{-1}$ ). A smaller organic carbon export may correspond to a larger $\log K_{D}$. The uncertain spatial and seasonal variations of carbon export may also affect the estimate of $\log K_{D}$. In addition, there are no available global data sets of SPM in the ML. GEOS-Chem derives SPM concentrations from MODIS satellite chlorophyll $a$ and $\mathrm{C}: \mathrm{Chl} a$ ratios (Soerensen et al., 2010b). Thus, the uncertain SPM fields may also affect $\log K_{D}$. As for the other two parameters (ER and $\mathrm{ER}_{\mathrm{Asia}}$ ), the parameter inversion decreases soil emission but increases Asian anthropogenic emission, consistent with the emission inversion (see Table 4).

Similar to our model-observation comparison for the emission inversion, we run GEOS-Chem using optimized parameters and calculate the NRMSEs for all ground-based sites (Table 1). A smaller average NRMSE of 0.14 for the parameter inversion than that of 0.16 for the reference simulation shows improvement in model performance. GEOSChem simulations using optimized parameters also match regional over-water $\mathrm{Hg}^{0}$ (NRMSE $=0.10$, Fig. 2) and wet deposition measurements (Fig. S9 in the Supplement). In addition, we evaluate the optimized model against recent surface ocean measurements of total aqueous mercury $\left(\mathrm{Hg}_{\mathrm{aq}}^{T}\right), \mathrm{Hg}_{\mathrm{aq}}^{0}$, and $\mathrm{Hg}_{\mathrm{aq}}^{\mathrm{P}}$ (Table 5). For $\mathrm{Hg}_{\mathrm{aq}}^{T}, 50$ and $75 \%$ (6 and 8 out of 12) of the modeled data from the reference and optimized simulations, respectively, are within measurement ranges. For $\mathrm{Hg}_{\mathrm{aq}}^{0}, 60 \%$ (6 out of 10) of the modeled data from both simulations are within measurement ranges. For $\mathrm{Hg}_{\mathrm{aq}}^{\mathrm{P}}$, the reference simulation predicts a higher value while the parameter inversion predicts a lower value than the only measurement data. These results suggest that the parameter inversion is comparable or potentially better than the reference simulation with regard to modeling surface ocean mercury.

Optimizing the two ocean model parameters, $-\log K_{\mathrm{OX} 2}$ and $\log K_{D}$, changes the global ocean Hg budget in GEOSChem, as shown in Fig. 6. Sources of $\mathrm{Hg}_{\mathrm{aq}}$ in the ML in-

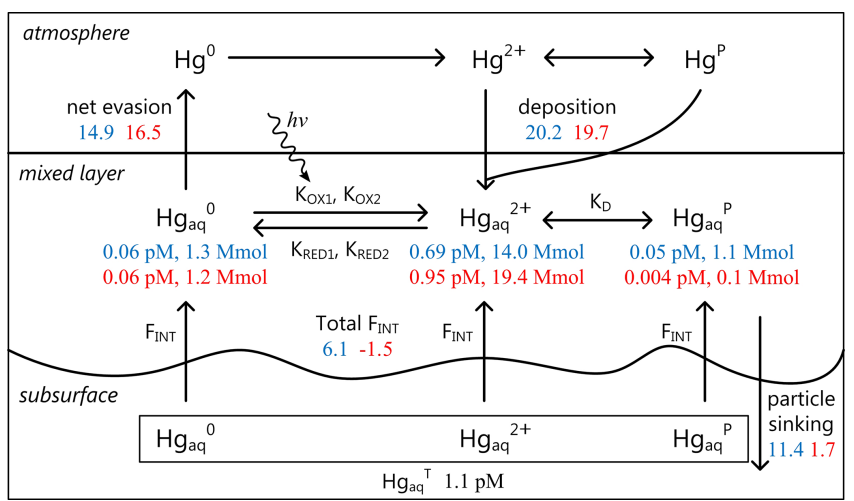

Figure 6. Global ocean mercury budget modeled by GEOS-Chem. Blue color indicates the reference simulation and red color the parameter inversion. Fluxes are in megamoles per year. Notations in this figure follow Soerensen et al. $(2010 b) . F_{\text {INT }}$ denotes net fluxes from subsurface waters through entrainment/detrainment of the mixed layer and Ekman pumping.

clude deposition of oxidized $\mathrm{Hg}$ and physical transport from subsurface waters. They are balanced by $\mathrm{Hg}^{0}$ evasion and $\mathrm{Hg}_{\mathrm{aq}}^{\mathrm{P}}$ sinking. In the reference simulation, although deposition (20.2 $\mathrm{Mmol} \mathrm{yr}^{-1}$ ) accounts for most $\mathrm{ML} \mathrm{Hg}_{\mathrm{aq}}$ inputs, the two physical transport processes, entrainment/detrainment of the ML and Ekman pumping, together supply a considerable amount ( $F_{\mathrm{INT}}$ : $6.1 \mathrm{Mmol} \mathrm{yr}^{-1}$ ) from subsurface waters. This upward flux is a result of the gradient in $\mathrm{Hg}_{\text {aq }}^{T}$ between the ML $(0.8 \mathrm{pM})$ and subsurface waters $(1.1 \mathrm{pM}) . \mathrm{Hg}^{0}$ evasion and $\mathrm{Hg}_{\mathrm{aq}}^{\mathrm{P}}$ sinking remove 14.9 and $11.4 \mathrm{Mmol} \mathrm{yr}^{-1}$ from the ML, respectively. The combined effect of the larger $K_{\mathrm{OX} 2}$ and smaller $K_{D}$ in the parameter inversion is, in the ML, that $\mathrm{Hg}_{\mathrm{aq}}^{2+}$ increases from 0.69 to $0.95 \mathrm{pM}, \mathrm{Hg}_{\mathrm{aq}}^{\mathrm{P}}$ decreases from 0.05 to $0.004 \mathrm{pM}$, and $\mathrm{Hg}_{\mathrm{aq}}^{0}$ remains $0.06 \mathrm{pM}$. $\mathrm{Hg}_{\mathrm{aq}}^{\mathrm{P}}$ sinking becomes a smaller sink $\left(1.7 \mathrm{Mmol} \mathrm{yr}^{-1}\right)$ due to the lower $K_{D}$. Physical transport contributes a downward flux $\left(-1.5 \mathrm{Mmol} \mathrm{yr}^{-1}\right)$ since the gradient of $\mathrm{Hg}_{\mathrm{aq}}^{T}$ between the ML $(1.0 \mathrm{pM})$ and subsurface waters $(1.1 \mathrm{pM})$ is diminished.

Physical transport and $\mathrm{Hg}_{\mathrm{aq}}^{\mathrm{P}}$ sinking affect seasonal variations of simulated $\mathrm{Hg}^{0}$ evasion from the ocean (Soerensen et al., 2010b). In summer, enhanced biological productivity increases $\mathrm{Hg}_{\mathrm{aq}}^{\mathrm{P}}$ sinking and decreases $\mathrm{Hg}^{0}$ evasion by shifting speciated $\mathrm{Hg}_{\mathrm{aq}}$ equilibrium in the ML towards $\mathrm{Hg}_{\mathrm{aq}}^{0}$ loss. During winter months, the ML deepens and $\mathrm{Hg}_{\mathrm{aq}}$ in subsurface waters invade the ML by entrainment; additionally, $\mathrm{Hg}^{0}$ evasion will be enhanced if subsurface waters contain higher $\mathrm{Hg}_{\mathrm{aq}}^{T}$. In the parameter inversion, physical transport and $\mathrm{Hg}_{\mathrm{aq}}^{\mathrm{P}}$ sinking are both weakened, as described above. As a result, the parameter inversion overturns seasonality of simulated ocean evasions in both hemispheres (Fig. 5), agreeing with results from the emission inversion.

As described in Sect. 2.6.4, we conduct an additional parameter inversion including six new elements representing $\mathrm{Br}$ 
Table 4. Evolution of the parameters' estimates in the parameter inversion.

\begin{tabular}{lrrrl}
\hline Parameter & A priori & First iteration & $\begin{array}{r}\text { Before second } \\
\text { iteration* }\end{array}$ & A posteriori \\
\hline$-\log K_{\mathrm{OX} 2}$ & $5.0 \pm 1.0$ & $5.1 \pm 0.1$ & $5.1 \pm 1.0$ & $5.2 \pm 0.1\left(K_{\left.\mathrm{OX} 2=6 \times 10^{-6} \mathrm{~s}^{-1}\right)}\right.$ \\
$\log K_{D}$ & $5.3 \pm 0.4$ & $4.4 \pm 0.2$ & $4.4 \pm 0.2$ & $4.2 \pm 0.2\left(K_{D}=1.6 \times 10^{4} \mathrm{~L} \mathrm{~kg}^{-1}\right)$ \\
$\mathrm{ER}_{\text {Soil }}$ & $1.0 \pm 0.5$ & $0.37 \pm 0.08$ & $0.37 \pm 0.19$ & $0.24 \pm 0.1($ soil emission decreases by $76 \%)$ \\
$\mathrm{ER}_{\text {Asia }}$ & $1.0 \pm 0.5$ & $1.7 \pm 0.1$ & $1.7 \pm 0.9$ & $1.9 \pm 0.1$ (Asian anthropogenic emission increases by $90 \%)$ \\
\hline
\end{tabular}

* For the second iteration, we use the best estimates derived from the first iteration, but larger parameter uncertainties. The uncertainty of 1.0 for - log $K_{\mathrm{OX} 2}$ is the same as that for the a priori estimate. The uncertainties for $\mathrm{ER}_{\mathrm{Soil}}$ and $\mathrm{ER}_{\mathrm{Asia}}$ are chosen as $50 \%$ of their best estimates, consistent with the emission inversion. The uncertainty for $\log K_{D}$ is chosen as 0.2 because it is approaching the lower end (4.2) of the possible values in the literature survey.

Table 5. Recent surface ocean mercury measurements and simulated concentrations. ${ }^{\mathrm{a}}$

\begin{tabular}{|c|c|c|c|c|c|c|}
\hline Location & Date & Latitude, longitude & Measurement & $\begin{array}{l}\text { Reference } \\
\text { simulation }^{b}\end{array}$ & $\begin{array}{l}\text { Parameter } \\
\text { inversion }^{\mathrm{b}}\end{array}$ & Ref. $^{c}$ \\
\hline \multicolumn{7}{|c|}{$\mathrm{Hg}_{\mathrm{aq}}^{T}(\mathrm{pM})$} \\
\hline \multirow[t]{8}{*}{ Atlantic Ocean } & Nov 2008 & $15-50^{\circ} \mathrm{N}, 20-5^{\circ} \mathrm{W}$ & $0.8-3.0$ & 0.64 & 0.89 & (1) \\
\hline & & $30-15^{\circ} \mathrm{S}, 0-15^{\circ} \mathrm{E}$ & $0.4-2.8$ & 0.48 & 0.97 & (1) \\
\hline & Apr-May 2009 & $15-50^{\circ} \mathrm{N}, 25-5^{\circ} \mathrm{W}$ & $0.4-2.3$ & 0.34 & 0.82 & (1) \\
\hline & & $50-15^{\circ} \mathrm{S}, 65-20^{\circ} \mathrm{W}$ & $0.5-1.5$ & 0.68 & 0.89 & (1) \\
\hline & Oct-Nov 2005 & $20^{\circ} \mathrm{S}-35^{\circ} \mathrm{N}, 25^{\circ} \mathrm{W}-10^{\circ} \mathrm{E}$ & $0.5-4.5$ & 0.63 & 1.2 & (2) \\
\hline & Jun 2008 & $32^{\circ} \mathrm{N}, 64^{\circ} \mathrm{W}$ & $0.6-1.0$ & 0.65 & 1.2 & (3) \\
\hline & Sep 2008-2009 & $25-35^{\circ} \mathrm{N}, 65-60^{\circ} \mathrm{W}$ & $0.6-0.9$ & 0.95 & 1.2 & (4) \\
\hline & Aug 2010 & $30-32^{\circ} \mathrm{N}, 65-60^{\circ} \mathrm{W}$ & $1.2-1.6$ & 0.91 & 1.2 & (4) \\
\hline \multirow[t]{3}{*}{ Pacific Ocean } & Mar 2006 & $20-50^{\circ} \mathrm{N}, 152^{\circ} \mathrm{W}$ & $0.5-1.9$ & 0.96 & 1.2 & $(5)$ \\
\hline & May 2009 & $30^{\circ} \mathrm{N}, 140^{\circ} \mathrm{W}$ & $0.2-0.4$ & 0.80 & 1.1 & (6) \\
\hline & Oct 2011 & $15^{\circ} \mathrm{S}-17^{\circ} \mathrm{N}, 175-155^{\circ} \mathrm{W}$ & $<0.5$ & 0.83 & 1.1 & (7) \\
\hline Southern Ocean & Mar-Apr 2008 & $66-44^{\circ} \mathrm{S}, 140-147^{\circ} \mathrm{E}$ & $0.6-2.8$ & 0.85 & 1.1 & (8) \\
\hline \multicolumn{7}{|c|}{$\mathrm{Hg}_{\mathrm{aq}}^{0}(\mathrm{fM})$} \\
\hline \multirow[t]{8}{*}{ Atlantic Ocean } & Nov 2008 & $15-50^{\circ} \mathrm{N}, 20-5^{\circ} \mathrm{W}$ & $30-140$ & 52 & 51 & (1) \\
\hline & & $30-15^{\circ} \mathrm{S}, 0-15^{\circ} \mathrm{E}$ & $15-30$ & 38 & 68 & (1) \\
\hline & Apr-May 2009 & $15-50^{\circ} \mathrm{N}, 25-5^{\circ} \mathrm{W}$ & $15-40$ & 27 & 55 & (1) \\
\hline & & $50-15^{\circ} \mathrm{S}, 65-20^{\circ} \mathrm{W}$ & $10-70$ & 54 & 59 & (1) \\
\hline & Jul 2005 & $60^{\circ} \mathrm{N}, 40^{\circ} \mathrm{W}-5^{\circ} \mathrm{E}$ & 30-90 & 22 & 83 & (9) \\
\hline & Sep 2008-2009 & $25-35^{\circ} \mathrm{N}, 65-60^{\circ} \mathrm{W}$ & $80-170$ & 80 & 87 & (4) \\
\hline & Jun 2009 & $32^{\circ} \mathrm{N}, 64^{\circ} \mathrm{W}$ & $105-135$ & 55 & 90 & (4) \\
\hline & Aug 2010 & $30-32^{\circ} \mathrm{N}, 65-60^{\circ} \mathrm{W}$ & $130-260$ & 77 & 94 & (4) \\
\hline Pacific Ocean & Oct 2011 & $15 \mathrm{~S}-17^{\circ} \mathrm{N}, 175-155^{\circ} \mathrm{W}$ & $<100$ & 71 & 81 & (7) \\
\hline Southern Ocean & Mar-Apr 2008 & $66-44^{\circ} \mathrm{S}, 140-147^{\circ} \mathrm{E}$ & $<280$ & 72 & 58 & (8) \\
\hline \multicolumn{7}{|c|}{$\mathrm{Hg}_{\mathrm{aq}}^{\mathrm{P}}(\mathrm{fM})$} \\
\hline Pacific Ocean & Oct 2011 & $15^{\circ} \mathrm{S}-17^{\circ} \mathrm{N}, 175-155^{\circ} \mathrm{W}$ & $20-50$ & 70 & 5 & (7) \\
\hline
\end{tabular}

${ }^{\mathrm{a}} 1 \mathrm{pM}=10^{-9} \mathrm{~mol} \mathrm{~m}^{-3} ; 1 \mathrm{fM}=10^{-12} \mathrm{~mol} \mathrm{~m}^{-3} \cdot{ }^{\mathrm{b}}$ Numbers in bold represent the modeled concentrations that are out of the corresponding measurement ranges. ${ }^{c}$ References: (1) Kuss et al. (2011), (2) Pohl et al. (2011), (3) Lamborg et al. (2012), (4) Soerensen et al. (2013), (5) Sunderland et al. (2009), (6) Hammerschmidt and Bowman (2012), (7) Munson (2014), (8) Cossa et al. (2011), and (9) Andersson et al. (2011).

columns in different latitudinal bands. As shown in the Supplement, Fig. S8, $-\log K_{\mathrm{OX} 2}$ is found to be strongly correlated with $\mathrm{Br}$ columns at $30-60^{\circ} \mathrm{N}, 30^{\circ} \mathrm{S}-0^{\circ}$, and $60-30^{\circ} \mathrm{S}$. The other three factors, $\log K_{D}, \mathrm{ER}_{\text {Soil }}$, and $\mathrm{ER}_{\mathrm{Asia}}$, have no or weak correlations with $\mathrm{Br}$ columns. Thus, we suggest that the inversion results of smaller terrestrial emissions and larger Asian anthropogenic emissions are not likely to be af- fected by the uncertainty in atmospheric chemistry, but the poor understanding of atmospheric chemistry may limit our ability to further constrain specific ocean model parameters. 


\subsection{Implications for the $\mathrm{Hg}$ biogeochemical cycle}

We use the box model developed by Amos et al. (2013, 2014) to explore the long-term impact of our inverted emissions and parameters on the global biogeochemical cycling of mercury. This seven-box model dynamically couples the atmosphere, three terrestrial reservoirs (fast, slow, and armored), and three ocean reservoirs (surface, subsurface, and deep). All rate coefficients of $\mathrm{Hg}$ mass between reservoirs are assumed to be of the first order. The simulation is initialized with geogenic emissions to represent the natural mercury cycle and, after reaching steady state, it is driven by historical anthropogenic emissions (Streets et al., 2011; Horowitz et al., 2014).

Two box-model simulations are performed. The first uses rate coefficients from the present-day global budget in the reference simulation. The second uses those from our emission and parameter inversions and has higher anthropogenic emissions, lower re-emission from terrestrial surfaces, and less sinking out of the surface ocean than the first one does (Table S4 in the Supplement). The second simulation obtains larger terrestrial mercury reservoirs, highlighting their important role in sequestering legacy mercury. The oceans are a smaller mercury reservoir of $\sim 1700 \mathrm{Mmol}$ in the second simulation, compared to that of $\sim 2000 \mathrm{Mmol}$ in the first simulation. The former number is more consistent with the estimates of about 1300-1400 Mmol by Lamborg et al. (2014) and Zhang et al. (2014). The first box-model simulation shows that $18 \%$ of present-day atmospheric deposition is from primary anthropogenic emissions, $76 \%$ is legacy, and $6 \%$ is natural (i.e., geogenic emissions). Applying our inversion results into the box model, the second simulation suggests that primary anthropogenic emissions account for a larger fraction (18-23\%) of present-day atmospheric deposition. Legacy releases of mercury contribute a smaller proportion $(72-76 \%)$ but still play a major role.

\section{Summary and conclusion}

Here, we perform global-scale inverse modeling combining ground-based $\mathrm{Hg}^{0}$ observations and GEOS-Chem mercury simulations. Using Bayesian inversion methods, we are able to constrain present-day mercury emission fluxes from major sources (emission inversion) and relevant key parameters in GEOS-Chem (parameter inversion), and reduce uncertainties associated with these fluxes and parameters.

The emission inversion better reproduces the groundbased $\mathrm{Hg}^{0}$ observations (particularly for sites in the Southern Hemisphere and North America) than the reference simulation and also matches measured $\mathrm{Hg}^{0}$ over the North Atlantic Ocean and wet deposition fluxes in North America. We obtain a global $\mathrm{Hg}$ emission of $5.8 \mathrm{Gg} \mathrm{gr}^{-1}$ (uncertainty range: $1.7-10.3 \mathrm{Gg} \mathrm{yr}^{-1}$ ), smaller than the estimate of $7.5 \mathrm{Gg} \mathrm{yr}^{-1}$ using a bottom-up approach (Pirrone et al., 2010). The global ocean accounts for $3.2 \mathrm{Gg} \mathrm{yr}^{-1} \mathrm{Hg}(55 \%$ of the total). The terrestrial ecosystem is neither a net source nor a net sink of atmospheric $\mathrm{Hg}^{0}$, in contrast to its bottomup estimate as a significant source (Pirrone et al., 2010). The optimized Asian anthropogenic emissions range from 650 to $1770 \mathrm{Mg} \mathrm{yr}^{-1}$, suggesting that bottom-up inventories $(550$ $800 \mathrm{Mg} \mathrm{yr}^{-1}$ ) may have underestimated their value. The total Asian $\mathrm{Hg}^{0}$ emission (including anthropogenic, natural and legacy sources) is estimated as $1180-2030 \mathrm{Mg} \mathrm{yr}^{-1}$, consistent with recent studies (Fu et al., 2015; Strode et al., 2008; Pan et al., 2007).

The emission inversion changes seasonal patterns of ocean emissions in both hemispheres. We identify and constrain two ocean model parameters in GEOS-Chem that can explain this seasonal pattern, the rate constant of dark oxidation of $\mathrm{Hg}_{\mathrm{aq}}^{0}\left(K_{\mathrm{OX} 2}\right)$ and the partition coefficient between $\mathrm{Hg}_{\mathrm{aq}}^{2+}$ and $\mathrm{Hg}_{\mathrm{aq}}^{\mathrm{P}}\left(K_{D}\right)$. The a posteriori $K_{\mathrm{OX} 2}\left(6 \times 10^{-6} \mathrm{~s}^{-1}\right)$ is larger than its current value in GEOS-Chem $\left(1 \times 10^{-7} \mathrm{~s}^{-1}\right)$, suggesting that dark oxidation of $\mathrm{Hg}_{\mathrm{aq}}^{0}$ is more important than previously thought. The a posteriori $\log K_{D}$ (4.2) is smaller than its a priori (5.3), leading to less $\mathrm{Hg}_{\mathrm{aq}}^{\mathrm{P}}$ sinking out of the mixed layer. These changes in parameters affect the simulated global ocean mercury budget, especially mass exchange between the mixed layer and subsurface waters. The parameter inversion changes seasonality of ocean emissions in both hemispheres, agreeing with results from the emission inversion.

Our inversion results suggest changes in our understanding of the timescales of cycling between different mercury reservoirs. Based on these changes, the long-term biogeochemical box-model simulations result in larger estimated terrestrial mercury pools and smaller ocean mercury pools. Legacy mercury accounts for a smaller fraction of present-day atmospheric deposition than previous estimates, whereas the contribution of primary anthropogenic emissions becomes larger (up to $23 \%$ ).

Our inversion results identify specific knowledge gaps in mercury observation and modeling that currently limit our ability to constrain the biogeochemical cycle of mercury. First, and most important, effective inversions are hampered by the uncertain atmospheric $\mathrm{Hg}$ measurements, particularly the large intercomparison errors in measured GEM. Only a few experiments have been made to evaluate the comparability of mercury measurements (Gustin et al., 2013). Our results show that intercomparison errors (about 10\%) dominate the total observational errors and thus limit the uncertainty reduction possible by our inverse approach. Our inversions only lead to moderate reductions of the average NRMSE (Sect. 3.1). Therefore, research aimed at quantifying and reducing the intercomparison errors should be given high priority by the mercury measurement community. Second, observational sites are sparse in some regions (e.g., the Southern Hemisphere). More sites in these regions are necessary to further constrain emissions. Third, the uncertainty in atmospheric mercury chemistry also affects our inversion re- 
sults (specifically, in constraining ocean model parameters). Improving our understanding of atmospheric mercury chemistry at both global and regional scales (e.g., the polar regions) requires a combination of both measurement and modeling advances.

\section{The Supplement related to this article is available online at doi:10.5194/acp-15-7103-2015-supplement.}

Acknowledgements. This work is supported by the US NSF Atmospheric Chemistry Program \#1053648. A. Dommergue, O. Magand, and $\mathrm{H}$. Angot acknowledge the EU-FP7 project GMOS, Labex OSUG@2020 (ANR10 LABX56) and LEFE CNRS/INSU (program SAMOA) for funding, and the French Polar Institute IPEV (Program 1028, GMOStral) for logistical and financial support. S. Kang and Q. Zhang acknowledge support by project NSFC (41225002). We thank Environment Canada, Ministry of the Environment (Japan), the SEARCH network (sponsored by Southern Company and EPRI), X. Feng and X. Fu (IGCAS, China), $\mathrm{K}$. Crist (Ohio University), and all other investigators for providing observational data, H. Amos (Harvard) for assistance and helpful discussions on the global biogeochemical box model, and J. Kuss (IOW, Germany), C. D. Holmes (FSU), Y. Zhang and E. S. Corbitt (Harvard) for helpful discussions. We also thank two anonymous referees for their helpful comments.

Edited by: A. Dastoor

\section{References}

AMAP/UNEP: Technical Background Report for the Global Mercury Assessment 2013, Arctic Monitoring and Assessment Programme, Oslo, Norway/UNEP Chemicals Branch Geneva, Switzerland, vi + 263 pp., 2013.

Amos, H. M., Jacob, D. J., Holmes, C. D., Fisher, J. A., Wang, Q., Yantosca, R. M., Corbitt, E. S., Galarneau, E., Rutter, A. P., Gustin, M. S., Steffen, A., Schauer, J. J., Graydon, J. A., Louis, V. L. St., Talbot, R. W., Edgerton, E. S., Zhang, Y., and Sunderland, E. M.: Gas-particle partitioning of atmospheric $\mathrm{Hg}(\mathrm{II})$ and its effect on global mercury deposition, Atmos. Chem. Phys., 12, 591-603, doi:10.5194/acp-12-591-2012, 2012.

Amos, H. M., Jacob, D. J., Streets, D. G., and Sunderland, E. M.: Legacy impacts of all-time anthropogenic emissions on the global mercury cycle, Global Biogeochem. Cy., 27, 410-421, doi:10.1002/gbc.20040, 2013.

Amos, H. M., Jacob, D. J., Kocman, D., Horowitz, H. M., Zhang, Y., Dutkiewicz, S., Horvat, M., Corbitt, E. S., Krabbenhoft, D. P., and Sunderland, E. M.: Global biogeochemical implications of mercury discharges from rivers and sediment burial, Environ. Sci. Technol., 48, 9514-9522, doi:10.1021/es502134t, 2014.

Amyot, M., Gill, G. A., and Morel, F. M. M.: Production and loss of dissolved gaseous mercury in coastal seawater, Environ. Sci. Technol., 31, 3606-3611, doi:10.1021/es9703685, 1997.
Andersson, M. E., Sommar, J., Gårdfeldt, K., and Jutterström, S.: Air-sea exchange of volatile mercury in the North Atlantic Ocean, Mar. Chem., 125, 1-7, doi:10.1016/j.marchem.2011.01.005, 2011.

Angot, H., Barret, M., Magand, O., Ramonet, M., and Dommergue, A.: A 2-year record of atmospheric mercury species at a background Southern Hemisphere station on Amsterdam Island, Atmos. Chem. Phys., 14, 11461-11473, doi:10.5194/acp14-11461-2014, 2014.

Antia, A. N., Koeve, W., Fischer, G., Blanz, T., Schulz-Bull, D., Schölten, J., Neuer, S., Kremling, K., Kuss, J., Peinert, R., Hebbeln, D., Bathmann, U., Conte, M., Fehner, U., and Zeitzschel, B.: Basin-wide particulate carbon flux in the Atlantic Ocean: Regional export patterns and potential for atmospheric $\mathrm{CO}_{2}$ sequestration, Global Biogeochem. Cy., 15, 845862, doi:10.1029/2000gb001376, 2001.

Aspmo, K., Gauchard, P.-A., Steffen, A., Temme, C., Berg, T., Bahlmann, E., Banic, C., Dommergue, A., Ebinghaus, R., Ferrari, C., Pirrone, N., Sprovieri, F., and Wibetoe, G.: Measurements of atmospheric mercury species during an international study of mercury depletion events at Ny-Ålesund, Svalbard, spring 2003. How reproducible are our present methods?, Atmos. Environ., 39, 7607-7619, doi:10.1016/j.atmosenv.2005.07.065, 2005.

Bagnato, E., Tamburello, G., Avard, G., Martinez-Cruz, M., Enrico, M., Fu, X., Sprovieri, M., and Sonke, J. E.: Mercury fluxes from volcanic and geothermal sources: an update, Geological Society, London, Special Publications, 410, 263-285, doi:10.1144/sp410.2, 2014.

Baker, D. F., Law, R. M., Gurney, K. R., Rayner, P., Peylin, P., Denning, A. S., Bousquet, P., Bruhwiler, L., Chen, Y. H., Ciais, P., Fung, I. Y., Heimann, M., John, J., Maki, T., Maksyutov, S., Masarie, K., Prather, M., Pak, B., Taguchi, S., and Zhu, Z.: TransCom 3 inversion intercomparison: Impact of transport model errors on the interannual variability of regional $\mathrm{CO}_{2}$ fluxes, 1988-2003, Global Biogeochem. Cy., 20, GB1002, doi:10.1029/2004gb002439, 2006.

Bash, J. O.: Description and initial simulation of a dynamic bidirectional air-surface exchange model for mercury in Community Multiscale Air Quality (CMAQ) model, J. Geophys. Res.Atmos., 115, D06305, doi:10.1029/2009jd012834, 2010.

Bash, J. O., Bresnahan, P., and Miller, D. R.: Dynamic surface interface exchanges of mercury: A review and compartmentalized modeling framework, J. Appl. Meteorol. Clim., 46, 1606-1618, doi:10.1175/jam2553.1, 2007.

Batrakova, N., Travnikov, O., and Rozovskaya, O.: Chemical and physical transformations of mercury in the ocean: a review, Ocean Sci., 10, 1047-1063, doi:10.5194/os-10-1047-2014, 2014.

Bey, I., Jacob, D. J., Yantosca, R. M., Logan, J. A., Field, B. D., Fiore, A. M., Li, Q., Liu, H. Y., Mickley, L. J., and Schultz, M. G.: Global modeling of tropospheric chemistry with assimilated meteorology: Model description and evaluation, J. Geophys. Res.-Atmos., 106, 23073-23095, doi:10.1029/2001jd000807, 2001.

Brunke, E.-G., Labuschagne, C., Ebinghaus, R., Kock, H. H., and Slemr, F.: Gaseous elemental mercury depletion events observed at Cape Point during 2007-2008, Atmos. Chem. Phys., 10, 11211131, doi:10.5194/acp-10-1121-2010, 2010. 
Brunner, D., Henne, S., Keller, C. A., Reimann, S., Vollmer, M. K., O'Doherty, S., and Maione, M.: An extended Kalman-filter for regional scale inverse emission estimation, Atmos. Chem. Phys., 12, 3455-3478, doi:10.5194/acp-12-3455-2012, 2012.

Bullock, O. R., Atkinson, D., Braverman, T., Civerolo, K., Dastoor, A., Davignon, D., Ku, J.-Y., Lohman, K., Myers, T. C., Park, R. J., Seigneur, C., Selin, N. E., Sistla, G., and Vijayaraghavan, K.: The North American Mercury Model Intercomparison Study (NAMMIS): Study description and modelto-model comparisons, J. Geophys. Res.-Atmos., 113, D17310, doi:10.1029/2008jd009803, 2008.

Bullock, O. R., Atkinson, D., Braverman, T., Civerolo, K., Dastoor, A., Davignon, D., Ku, J.-Y., Lohman, K., Myers, T. C., Park, R. J., Seigneur, C., Selin, N. E., Sistla, G., and Vijayaraghavan, K.: An analysis of simulated wet deposition of mercury from the North American Mercury Model Intercomparison Study, J. Geophys. Res.-Atmos., 114, D08301, doi:10.1029/2008jd011224, 2009.

Chen, Y.-H. and Prinn, R. G.: Estimation of atmospheric methane emissions between 1996 and 2001 using a three-dimensional global chemical transport model, J. Geophys. Res., 111, D10307, doi:10.1029/2005jd006058, 2006.

Cheng, I., Zhang, L., Mao, H., Blanchard, P., Tordon, R., and Dalziel, J.: Seasonal and diurnal patterns of speciated atmospheric mercury at a coastal-rural and a coastal-urban site, Atmos. Environ., 82, 193-205, doi:10.1016/j.atmosenv.2013.10.016, 2014.

Cole, A. S., Steffen, A., Pfaffhuber, K. A., Berg, T., Pilote, M., Poissant, L., Tordon, R., and Hung, H.: Ten-year trends of atmospheric mercury in the high Arctic compared to Canadian subArctic and mid-latitude sites, Atmos. Chem. Phys., 13, 15351545, doi:10.5194/acp-13-1535-2013, 2013.

Cole, A. S., Steffen, A., Eckley, C. S., Narayan, J., Pilote, M., Tordon, R., Graydon, J. A., St. Louis, V. L., Xu, X., and Branfireun, B. A.: A survey of mercury in air and precipitation across Canada: patterns and trends, Atmosphere, 5, 635-668, doi:10.3390/atmos5030635, 2014.

Cossa, D., Heimbürger, L.-E., Lannuzel, D., Rintoul, S. R., Butler, E. C. V., Bowie, A. R., Averty, B., Watson, R. J., and Remenyi, T.: Mercury in the Southern Ocean, Geochim. Cosmochim. Ac., 75, 4037-4052, doi:10.1016/j.gca.2011.05.001, 2011.

Dastoor, A. P. and Durnford, D. A.: Arctic Ocean: Is it a sink or a source of atmospheric mercury?, Environ. Sci. Technol., 48, 1707-1717, doi:10.1021/es404473e, 2013.

de Foy, B., Wiedinmyer, C., and Schauer, J. J.: Estimation of mercury emissions from forest fires, lakes, regional and local sources using measurements in Milwaukee and an inverse method, Atmos. Chem. Phys., 12, 8993-9011, doi:10.5194/acp-12-89932012, 2012.

de Foy, B., Heo, J., and Schauer, J. J.: Estimation of direct emissions and atmospheric processing of reactive mercury using inverse modeling, Atmos. Environ., 85, 73-82, doi:10.1016/j.atmosenv.2013.11.070, 2014.

Demers, J. D., Blum, J. D., and Zak, D. R.: Mercury isotopes in a forested ecosystem: Implications for air-surface exchange dynamics and the global mercury cycle, Global Biogeochem. Cy., 27, 222-238, doi:10.1002/gbc.20021, 2013.

Denkenberger, J. S., Driscoll, C. T., Branfireun, B. A., Eckley, C. S., Cohen, M., and Selvendiran, P.: A synthesis of rates and controls on elemental mercury evasion in the Great Lakes Basin, Environ. Pollut., 161, 291-298, doi:10.1016/j.envpol.2011.06.007, 2012.

De Simone, F., Gencarelli, C. N., Hedgecock, I. M., and Pirrone, N.: Global atmospheric cycle of mercury: a model study on the impact of oxidation mechanisms, Environ. Sci. Pollut. R., 21, 4110 4123, doi:10.1007/s11356-013-2451-x, 2014.

Dibble, T. S., Zelie, M. J., and Mao, H.: Thermodynamics of reactions of $\mathrm{ClHg}$ and $\mathrm{BrHg}$ radicals with atmospherically abundant free radicals, Atmos. Chem. Phys., 12, 10271-10279, doi:10.5194/acp-12-10271-2012, 2012.

Driscoll, C. T., Mason, R. P., Chan, H. M., Jacob, D. J., and Pirrone, N.: Mercury as a global pollutant: sources, pathways, and effects, Environ. Sci. Technol., 47, 4967-4983, doi:10.1021/es305071v, 2013.

Durnford, D., Dastoor, A., Figueras-Nieto, D., and Ryjkov, A.: Long range transport of mercury to the Arctic and across Canada, Atmos. Chem. Phys., 10, 6063-6086, doi:10.5194/acp-10-60632010, 2010.

Ebinghaus, R., Jennings, S. G., Schroeder, W. H., Berg, T., Donaghy, T., Guentzel, J., Kenny, C., Kock, H. H., Kvietkus, K., Landing, W., Mühleck, T., Munthe, J., Prestbo, E. M., Schneeberger, D., Slemr, F., Sommar, J., Urba, A., Wallschläger, D., and Xiao, Z.: International field intercomparison measurements of atmospheric mercury species at Mace Head, Ireland, Atmos. Environ., 33, 3063-3073, doi:10.1016/S1352-2310(98)00119-8, 1999.

Ebinghaus, R., Jennings, S. G., Kock, H. H., Derwent, R. G., Manning, A. J., and Spain, T. G.: Decreasing trends in total gaseous mercury observations in baseline air at Mace Head, Ireland from 1996 to 2009, Atmos. Environ., 45, 3475-3480, doi:10.1016/j.atmosenv.2011.01.033, 2011.

Edwards, G. C. and Howard, D. A.: Air-surface exchange measurements of gaseous elemental mercury over naturally enriched and background terrestrial landscapes in Australia, Atmos. Chem. Phys., 13, 5325-5336, doi:10.5194/acp-13-5325-2013, 2013.

Ericksen, J. A., Gustin, M. S., Xin, M., Weisberg, P. J., and Fernandez, G. C. J.: Air-soil exchange of mercury from background soils in the United States, Sci. Total Environ., 366, 851-863, doi:10.1016/j.scitotenv.2005.08.019, 2006.

Fisher, J. A., Jacob, D. J., Soerensen, A. L., Amos, H. M., Steffen, A., and Sunderland, E. M.: Riverine source of Arctic Ocean mercury inferred from atmospheric observations, Nat. Geosci., 5, 499-504, doi:10.1038/ngeo1478, 2012.

Fitzgerald, W. F., Lamborg, C. H., and Hammerschmidt, C. R.: Marine biogeochemical cycling of mercury, Chem. Rev., 107, 641662, doi:10.1021/cr050353m, 2007.

Friedli, H. R., Arellano, A. F., Cinnirella, S., and Pirrone, N.: Initial estimates of mercury emissions to the atmosphere from global biomass burning, Environ. Sci. Technol., 43, 3507-3513, doi:10.1021/es802703g, 2009.

Fu, X. W., Feng, X., Dong, Z. Q., Yin, R. S., Wang, J. X., Yang, Z. R., and Zhang, H.: Atmospheric gaseous elemental mercury (GEM) concentrations and mercury depositions at a high-altitude mountain peak in south China, Atmos. Chem. Phys., 10, 24252437, doi:10.5194/acp-10-2425-2010, 2010.

Fu, X. W., Feng, X., Liang, P., Deliger, Zhang, H., Ji, J., and Liu, P.: Temporal trend and sources of speciated atmospheric mercury at Waliguan GAW station, Northwestern China, Atmos. Chem. Phys., 12, 1951-1964, doi:10.5194/acp-12-1951-2012, 2012a. 
Fu, X. W., Feng, X., Shang, L. H., Wang, S. F., and Zhang, H.: Two years of measurements of atmospheric total gaseous mercury (TGM) at a remote site in Mt. Changbai area, Northeastern China, Atmos. Chem. Phys., 12, 4215-4226, doi:10.5194/acp12-4215-2012, 2012b.

Fu, X. W., Zhang, H., Lin, C.-J., Feng, X. B., Zhou, L. X., and Fang, S. X.: Correlation slopes of GEM / CO, GEM / $\mathrm{CO}_{2}$, and $\mathrm{GEM} / \mathrm{CH}_{4}$ and estimated mercury emissions in China, South Asia, the Indochinese Peninsula, and Central Asia derived from observations in northwestern and southwestern China, Atmos. Chem. Phys., 15, 1013-1028, doi:10.5194/acp-15-1013-2015, 2015.

Gårdfeldt, K. and Jonsson, M.: Is bimolecular reduction of $\mathrm{Hg}$ (II) complexes possible in aqueous systems of environmental importance, J. Phys. Chem. A, 107, 4478-4482, doi:10.1021/jp0275342, 2003.

Gay, D. A., Schmeltz, D., Prestbo, E., Olson, M., Sharac, T., and Tordon, R.: The Atmospheric Mercury Network: measurement and initial examination of an ongoing atmospheric mercury record across North America, Atmos. Chem. Phys., 13, 1133911349, doi:10.5194/acp-13-11339-2013, 2013.

Goodsite, M. E., Plane, J. M. C., and Skov, H.: Correction to a theoretical study of the oxidation of $\mathrm{Hg}^{0}$ to $\mathrm{HgBr}_{2}$ in the troposphere, Environ. Sci. Technol., 46, 5262-5262, doi:10.1021/es301201c, 2012.

Grant, S. L., Kim, M., Lin, P., Crist, K. C., Ghosh, S., and Kotamarthi, V. R.: A simulation study of atmospheric mercury and its deposition in the Great Lakes, Atmos. Environ., 94, 164-172, doi:10.1016/j.atmosenv.2014.05.033, 2014.

Gratz, L. E., Shah, V., Ambrose, J. L., Jaffe, D. A., Jaeglé, L., Stutz, J., Festa, J., Spolaor, M., Tsai, C., Selin, N. E., Song, S., Zhou, X., Weinheimer, A., Knapp, D., Montzka, D., Flocke, F., Campos, T., Apel, E., Hornbrook, R., Blake, N., Hall, S., Tyndall, G., Reeves M., Stechman, D., and Stell, M.: Oxidation of mercury by bromine in the subtropical Pacific free troposphere, Nat. Geosci., in review, 2015.

Graydon, J. A., St. Louis, V. L., Hintelmann, H., Lindberg, S. E., Sandilands, K. A., Rudd, J. W. M., Kelly, C. A., Hall, B. D., and Mowat, L. D.: Long-term wet and dry deposition of total and methyl mercury in the remote boreal ecoregion of Canada, Environ. Sci. Technol., 42, 8345-8351, doi:10.1021/es801056j, 2008.

Gurney, K. R., Law, R. M., Denning, A. S., Rayner, P. J., Baker, D., Bousquet, P., Bruhwiler, L., Chen, Y.-H., Ciais, P., Fan, S., Fung, I. Y., Gloor, M., Heimann, M., Higuchi, K., John, J., Maki, T., Maksyutov, S., Masarie, K., Peylin, P., Prather, M., Pak, B. C., Randerson, J., Sarmiento, J., Taguchi, S., Takahashi, T., and Yuen, C.-W.: Towards robust regional estimates of $\mathrm{CO}_{2}$ sources and sinks using atmospheric transport models, Nature, 415, 626630, doi:10.1038/415626a, 2002.

Gustin, M. S., Lindberg, S. E., and Weisberg, P. J.: An update on the natural sources and sinks of atmospheric mercury, Appl. Geochem., 23, 482-493, doi:10.1016/j.apgeochem.2007.12.010, 2008.

Gustin, M. S., Huang, J., Miller, M. B., Peterson, C., Jaffe, D. A., Ambrose, J., Finley, B. D., Lyman, S. N., Call, K., Talbot, R., Feddersen, D., Mao, H., and Lindberg, S. E.: Do we understand what the mercury speciation instruments are actually measur- ing? Results of RAMIX, Environ. Sci. Technol., 47, 7295-7306, doi:10.1021/es3039104, 2013.

Hammerschmidt, C. R. and Bowman, K. L.: Vertical methylmercury distribution in the subtropical North Pacific Ocean, Mar. Chem., 132-133, 77-82, doi:10.1016/j.marchem.2012.02.005, 2012.

Henson, S. A., Sanders, R., Madsen, E., Morris, P. J., Le Moigne, F., and Quartly, G. D.: A reduced estimate of the strength of the ocean's biological carbon pump, Geophys. Res. Lett., 38, L04606, doi:10.1029/2011g1046735, 2011.

Holmes, C. D., Jacob, D. J., Corbitt, E. S., Mao, J., Yang, X., Talbot, R., and Slemr, F.: Global atmospheric model for mercury including oxidation by bromine atoms, Atmos. Chem. Phys., 10, 12037-12057, doi:10.5194/acp-10-12037-2010, 2010.

Horowitz, H. M., Jacob, D. J., Amos, H. M., Streets, D. G., and Sunderland, E. M.: Historical mercury releases from commercial products: global environmental implications, Environ. Sci. Technol., 48, 10242-10250, doi:10.1021/es501337j, 2014.

Huang, J., Golombek, A., Prinn, R., Weiss, R., Fraser, P., Simmonds, P., Dlugokencky, E. J., Hall, B., Elkins, J., Steele, P., Langenfelds, R., Krummel, P., Dutton, G., and Porter, L.: Estimation of regional emissions of nitrous oxide from 1997 to 2005 using multinetwork measurements, a chemical transport model, and an inverse method, J. Geophys. Res.-Atmos., 113, D17313, doi:10.1029/2007jd009381, 2008.

Hynes, A., Donohoue, D., Goodsite, M., and Hedgecock, I.: Our current understanding of major chemical and physical processes affecting mercury dynamics in the atmosphere and at the airwater/terrestrial interfaces, in: Mercury Fate and Transport in the Global Atmosphere, edited by: Mason, R. and Pirrone, N., Springer US, New York, NY, USA, 427-457, 2009.

Jaffe, D., Prestbo, E., Swartzendruber, P., Weiss-Penzias, P., Kato, S., Takami, A., Hatakeyama, S., and Kajii, Y.: Export of atmospheric mercury from Asia, Atmos. Environ., 39, 3029-3038, doi:10.1016/j.atmosenv.2005.01.030, 2005.

Jaffe, D. A., Lyman, S., Amos, H. M., Gustin, M. S., Huang, J., Selin, N. E., Levin, L., ter Schure, A., Mason, R. P., Talbot, R., Rutter, A., Finley, B., Jaeglé, L., Shah, V., McClure, C., Ambrose, J., Gratz, L., Lindberg, S., Weiss-Penzias, P., Sheu, G.-R., Feddersen, D., Horvat, M., Dastoor, A., Hynes, A. J., Mao, H., Sonke, J. E., Slemr, F., Fisher, J. A., Ebinghaus, R., Zhang, Y., and Edwards, G.: Progress on understanding atmospheric mercury hampered by uncertain measurements, Environ. Sci. Technol., 48, 7204-7206, doi:10.1021/es5026432, 2014.

Kentisbeer, J., Leeson, S. R., Malcolm, H. M., Leith, I. D., Braban, C. F., and Cape, J. N.: Patterns and source analysis for atmospheric mercury at Auchencorth Moss, Scotland, Environ. Sci.-Process Impacts, 16, 1112-1123, doi:10.1039/c3em00700f, 2014.

Kikuchi, T., Ikemoto, H., Takahashi, K., Hasome, H., and Ueda, H.: Parameterizing soil emission and atmospheric oxidationreduction in a model of the global biogeochemical cycle of mercury, Environ. Sci. Technol., 47, 12266-12274, doi:10.1021/es401105h, 2013.

Kocman, D., Horvat, M., Pirrone, N., and Cinnirella, S.: Contribution of contaminated sites to the global mercury budget, Environ. Res., 125, 160-170, doi:10.1016/j.envres.2012.12.011, 2013.

Krüger, O., Ebinghaus, R., Kock, H. H., Richter-Politz, I., and Geilhufe, C.: Inverse modelling of gaseous mercury emissions at the 
contaminated industrial site BSL Werk Schkopau, in: Mercury Contaminated Sites - Characterization, Risk Assessment and Remediation, edited by: Ebinghaus, R., Turner, R. R., Lacerda, D., Vasiliev, O., and Salomons, W., Springer Environmental Science, Springer, Heidelberg, 377-392, 1999.

Kuss, J.: Water-air gas exchange of elemental mercury: An experimentally determined mercury diffusion coefficient for $\mathrm{Hg}^{0}$ water-air flux calculations, Limnol. Oceanogr., 59, 1461-1467, doi:10.4319/lo.2014.59.5.1461, 2014.

Kuss, J., Holzmann, J., and Ludwig, R.: An elemental mercury diffusion coefficient for natural waters determined by molecular dynamics simulation, Environ. Sci. Technol., 43, 3183-3186, doi:10.1021/es8034889, 2009.

Kuss, J., Zülicke, C., Pohl, C., and Schneider, B.: Atlantic mercury emission determined from continuous analysis of the elemental mercury sea-air concentration difference within transects between $50^{\circ} \mathrm{N}$ and $50^{\circ} \mathrm{S}$, Global Biogeochem. Cy., 25, GB3021, doi:10.1029/2010gb003998, 2011.

Lalonde, J. D., Amyot, M., Kraepiel, A. M. L., and Morel, F. M. M.: Photooxidation of $\operatorname{Hg}(0)$ in artificial and natural waters, Environ. Sci. Technol., 35, 1367-1372, doi:10.1021/es001408z, 2001.

Lalonde, J. D., Amyot, M., Orvoine, J., Morel, F. M. M., Auclair, J.-C., and Ariya, P. A.: Photoinduced oxidation of $\mathrm{Hg}^{0}$ (aq) in the waters from the St. Lawrence Estuary, Environ. Sci. Technol., 38, 508-514, doi:10.1021/es034394g, 2004.

Lamborg, C. H., Hammerschmidt, C. R., Gill, G. A., Mason, R. P., and Gichuki, S.: An intercomparison of procedures for the determination of total mercury in seawater and recommendations regarding mercury speciation during GEOTRACES cruises, Limnol. Oceanogr.-Meth., 10, 90-100, doi:10.4319/lom.2012.10.90, 2012.

Lamborg, C. H., Hammerschmidt, C. R., Bowman, K. L., Swarr, G. J., Munson, K. M., Ohnemus, D. C., Lam, P. J., Heimburger, L.-E., Rijkenberg, M. J. A., and Saito, M. A.: A global ocean inventory of anthropogenic mercury based on water column measurements, Nature, 512, 65-68, doi:10.1038/nature13563, 2014.

Lan, X., Talbot, R., Castro, M., Perry, K., and Luke, W.: Seasonal and diurnal variations of atmospheric mercury across the US determined from AMNet monitoring data, Atmos. Chem. Phys., 12, 10569-10582, doi:10.5194/acp-12-10569-2012, 2012.

Lei, H., Liang, X.-Z., Wuebbles, D. J., and Tao, Z.: Model analyses of atmospheric mercury: present air quality and effects of transpacific transport on the United States, Atmos. Chem. Phys., 13, 10807-10825, doi:10.5194/acp-13-10807-2013, 2013.

Lin, C. J. and Pehkonen, S. O.: The chemistry of atmospheric mercury: a review, Atmos. Environ., 33, 2067-2079, doi:10.1016/s1352-2310(98)00387-2, 1999.

Lin, C.-J., Gustin, M. S., Singhasuk, P., Eckley, C., and Miller, M.: Empirical models for estimating mercury flux from soils, Environ. Sci. Technol., 44, 8522-8528, doi:10.1021/es1021735, 2010.

Lindberg, S., Bullock, R., Ebinghaus, R., Engstrom, D., Feng, X., Fitzgerald, W., Pirrone, N., Prestbo, E., and Seigneur, C.: A synthesis of progress and uncertainties in attributing the sources of mercury in deposition, AMBIO: A Journal of the Human Environment, 36, 19-33, doi:10.1579/00447447(2007)36[19:asopau]2.0.co;2, 2007.

Locatelli, R., Bousquet, P., Chevallier, F., Fortems-Cheney, A., Szopa, S., Saunois, M., Agusti-Panareda, A., Bergmann, D.,
Bian, H., Cameron-Smith, P., Chipperfield, M. P., Gloor, E., Houweling, S., Kawa, S. R., Krol, M., Patra, P. K., Prinn, R. G., Rigby, M., Saito, R., and Wilson, C.: Impact of transport model errors on the global and regional methane emissions estimated by inverse modelling, Atmos. Chem. Phys., 13, $9917-$ 9937, doi:10.5194/acp-13-9917-2013, 2013.

Loux, N. T.: A critical assessment of elemental mercury air/water exchange parameters, Chem. Spec. Bioavailab., 16, 127-138, doi:10.3184/095422904782775018, 2004.

Lyman, S. N., Gustin, M. S., Prestbo, E. M., and Marsik, F. J.: Estimation of dry deposition of atmospheric mercury in Nevada by direct and indirect methods, Environ. Sci. Technol., 41, 19701976, doi:10.1021/es062323m, 2007.

Mason, R.: Mercury emissions from natural processes and their importance in the global mercury cycle, in: Mercury Fate and Transport in the Global Atmosphere, edited by: Mason, R. and Pirrone, N., Springer US, New York, NY, USA, 173-191, 2009.

Mason, R. P. and Fitzgerald, W. F.: The distribution and biogeochemical cycling of mercury in the equatorial Pacific Ocean, Deep-Sea Res. Pt. I, 40, 1897-1924, doi:10.1016/09670637(93)90037-4, 1993.

Mason, R. P. and Sheu, G. R.: Role of the ocean in the global mercury cycle, Global Biogeochem. Cy., 16, 1093, doi:10.1029/2001gb001440, 2002.

Mason, R. P., Rolfhus, K. R., and Fitzgerald, W. F.: Mercury in the North Atlantic, Mar. Chem., 61, 37-53, doi:10.1016/S03044203(98)00006-1, 1998.

Mason, R. P., Choi, A. L., Fitzgerald, W. F., Hammerschmidt, C. R., Lamborg, C. H., Soerensen, A. L., and Sunderland, E. M.: Mercury biogeochemical cycling in the ocean and policy implications, Environ. Res., 119, 101-117, doi:10.1016/j.envres.2012.03.013, 2012.

McClure, C., Jaffe, D. A., and Edgerton, E. S.: Evaluation of the $\mathrm{KCl}$ denuder method for gaseous oxidized mercury using $\mathrm{HgBr}_{2}$ at an in-service AMNet site, Environ. Sci. Technol., 48, 1143711444, doi:10.1021/es502545k, 2014.

Mergler, D., Anderson, H. A., Chan, L. H. M., Mahaffey, K. R., Murray, M., Sakamoto, M., and Stern, A. H.: Methylmercury exposure and health effects in humans: a worldwide concern, AMBIO: A Journal of the Human Environment, 36, 3-11, doi:10.1579/0044-7447(2007)36[3:meahei]2.0.co;2, 2007.

MOEJ: Ministry of the Environment, Japan: Monitoring results of atmosphere mercury background concentration, available at: http://www.env.go.jp/press/press.php?serial=16473 (last access: 25 June 2015), 2013 (in Japanese).

Müller, D., Wip, D., Warneke, T., Holmes, C. D., Dastoor, A., and Notholt, J.: Sources of atmospheric mercury in the tropics: continuous observations at a coastal site in Suriname, Atmos. Chem Phys., 12, 7391-7397, doi:10.5194/acp-12-7391-2012, 2012.

Munson, K. M.: Transformations of mercury in the marine water column, PhD Thesis, Joint Program in Oceanography (Massachusetts Institute of Technology, Department of Earth, Atmospheric, and Planetary Sciences; and the Woods Hole Oceanographic Institution), available at: http://hdl.handle.net/1721.1/ 87513 (last access: 25 June 2015), 2014.

Muntean, M., Janssens-Maenhout, G., Song, S., Selin, N. E., Olivier, J. G. J., Guizzardi, D., Maas, R., and Dentener, F.: Trend analysis from 1970 to 2008 and model evaluation of EDGARv4 global gridded anthropogenic mercury emissions, Sci. Total En- 
viron., 494-495, 337-350, doi:10.1016/j.scitotenv.2014.06.014, 2014.

Munthe, J., Wängberg, I., Pirrone, N., Iverfeldt, Å., Ferrara, R., Ebinghaus, R., Feng, X., Gårdfeldt, K., Keeler, G., Lanzillotta, E., Lindberg, S. E., Lu, J., Mamane, Y., Prestbo, E., Schmolke, S., Schroeder, W. H., Sommar, J., Sprovieri, F., Stevens, R. K., Stratton, W., Tuncel, G., and Urba, A.: Intercomparison of methods for sampling and analysis of atmospheric mercury species, Atmos. Environ., 35, 3007-3017, doi:10.1016/S13522310(01)00104-2, 2001

NADP/MDN: Mercury Deposition Network, National Atmospheric Deposition Program, available at: http://nadp.sws.uiuc.edu/mdn/ (last access: 25 June 2015), 2012.

Obrist, D., Pokharel, A. K., and Moore, C.: Vertical profile measurements of soil air suggest immobilization of gaseous elemental mercury in mineral soil, Environ. Sci. Technol., 48, 2242-2252, doi:10.1021/es4048297, 2014.

Pacyna, E. G., Pacyna, J. M., Sundseth, K., Munthe, J., Kindbom, K., Wilson, S., Steenhuisen, F., and Maxson, P.: Global emission of mercury to the atmosphere from anthropogenic sources in 2005 and projections to 2020, Atmos. Environ., 44, 2487-2499, doi:10.1016/j.atmosenv.2009.06.009, 2010.

Pan, L., Chai, T., Carmichael, G. R., Tang, Y., Streets, D., Woo, J.-H., Friedli, H. R., and Radke, L. F.: Top-down estimate of mercury emissions in China using four-dimensional variational data assimilation, Atmos. Environ., 41, 2804-2819, doi:10.1016/j.atmosenv.2006.11.048, 2007.

Park, S.-Y., Kim, P.-R., and Han, Y.-J.: Mercury exchange flux from two different soil types and affecting parameters, Asian J. Atmos. Environ., 7, 199-208, doi:10.5572/ajae.2013.7.4.199, 2013.

Parrella, J. P., Jacob, D. J., Liang, Q., Zhang, Y., Mickley, L. J., Miller, B., Evans, M. J., Yang, X., Pyle, J. A., Theys, N., and Van Roozendael, M.: Tropospheric bromine chemistry: implications for present and pre-industrial ozone and mercury, Atmos. Chem. Phys., 12, 6723-6740, doi:10.5194/acp-12-6723-2012, 2012.

Pfaffhuber, K. A., Berg, T., Hirdman, D., and Stohl, A.: Atmospheric mercury observations from Antarctica: seasonal variation and source and sink region calculations, Atmos. Chem. Phys., 12, 3241-3251, doi:10.5194/acp-12-3241-2012, 2012.

Pirrone, N., Cinnirella, S., Feng, X., Finkelman, R. B., Friedli, H. R., Leaner, J., Mason, R., Mukherjee, A. B., Stracher, G. B., Streets, D. G., and Telmer, K.: Global mercury emissions to the atmosphere from anthropogenic and natural sources, Atmos. Chem. Phys., 10, 5951-5964, doi:10.5194/acp-10-59512010, 2010.

Pirrone, N., Aas, W., Cinnirella, S., Ebinghaus, R., Hedgecock, I. M., Pacyna, J., Sprovieri, F., and Sunderland, E. M.: Toward the next generation of air quality monitoring: Mercury, Atmos. Environ., 80, 599-611, doi:10.1016/j.atmosenv.2013.06.053, 2013.

Pohl, C., Croot, P. L., Hennings, U., Daberkow, T., Budeus, G., and Loeff, M. R. v. d.: Synoptic transects on the distribution of trace elements ( $\mathrm{Hg}, \mathrm{Pb}, \mathrm{Cd}, \mathrm{Cu}, \mathrm{Ni}, \mathrm{Zn}, \mathrm{Co}, \mathrm{Mn}, \mathrm{Fe}$, and $\mathrm{Al})$ in surface waters of the Northern- and Southern East Atlantic, J. Marine Syst., 84, 28-41, doi:10.1016/j.jmarsys.2010.08.003, 2011.

Poissant, L., Pilote, M., Beauvais, C., Constant, P., and Zhang, H. H.: A year of continuous measurements of three atmospheric mercury species (GEM, RGM and Hgp) in southern Québec, Canada, Atmos. Environ., 39, 1275-1287, doi:10.1016/j.atmosenv.2004.11.007, 2005.
Pongprueksa, P., Lin, C. J., Singhasuk, P., Pan, L., Ho, T. C., and Chu, H. W.: Application of CMAQ at a hemispheric scale for atmospheric mercury simulations, Geosci. Model Dev. Discuss., 4, 1723-1754, doi:10.5194/gmdd-4-1723-2011, 2011.

Prinn, R. G.: Measurement equation for trace chemicals in fluids and solution of its inverse, in: Inverse Methods in Global Biogeochemical Cycles, Geophys. Monogr. Ser., AGU, Washington, DC, USA, 3-18, 2000.

Prinn, R. G., Heimbach, P., Rigby, M., Dutkiewicz, S., Melillo, J. M., Reilly, J. M., Kicklighter, D. W., and Waugh, C.: A strategy for a global observing system for verification of national greenhouse gas emissions, MIT Joint Program on the Science and Policy of Global Change, available at: http://globalchange.mit.edu/ research/publications/2161 (last access: 25 June 2015), 2011.

Qureshi, A., O'Driscoll, N. J., MacLeod, M., Neuhold, Y.-M., and Hungerbühler, K.: Photoreactions of mercury in surface ocean water: gross reaction kinetics and possible pathways, Environ. Sci. Technol., 44, 644-649, doi:10.1021/es9012728, 2010.

Rafaj, P., Bertok, I., Cofala, J., and Schöpp, W.: Scenarios of global mercury emissions from anthropogenic sources, Atmos. Environ., 79, 472-479, doi:10.1016/j.atmosenv.2013.06.042, 2013.

Rigby, M., Manning, A. J., and Prinn, R. G.: The value of highfrequency, high-precision methane isotopologue measurements for source and sink estimation, J. Geophys. Res.-Atmos., 117, D12312, doi:10.1029/2011jd017384, 2012.

Roustan, Y. and Bocquet, M.: Inverse modelling for mercury over Europe, Atmos. Chem. Phys., 6, 3085-3098, doi:10.5194/acp-63085-2006, 2006.

Saikawa, E., Rigby, M., Prinn, R. G., Montzka, S. A., Miller, B. R., Kuijpers, L. J. M., Fraser, P. J. B., Vollmer, M. K., Saito, T., Yokouchi, Y., Harth, C. M., Mühle, J., Weiss, R. F., Salameh, P. K., Kim, J., Li, S., Park, S., Kim, K.-R., Young, D., O’Doherty, S., Simmonds, P. G., McCulloch, A., Krummel, P. B., Steele, L. P., Lunder, C., Hermansen, O., Maione, M., Arduini, J., Yao, B., Zhou, L. X., Wang, H. J., Elkins, J. W., and Hall, B.: Global and regional emission estimates for HCFC-22, Atmos. Chem. Phys., 12, 10033-10050, doi:10.5194/acp-12-10033-2012, 2012.

Sanders, R., Henson, S. A., Koski, M., De La Rocha, C. L., Painter, S. C., Poulton, A. J., Riley, J., Salihoglu, B., Visser, A., Yool, A., Bellerby, R., and Martin, A. P.: The biological carbon pump in the North Atlantic, Prog. Oceanogr., 129, 200-218, doi:10.1016/j.pocean.2014.05.005, 2014.

Schroeder, W. H., Keeler, G., Kock, H., Roussel, P., Schneeberger, D., and Schaedlich, F.: International field intercomparison of atmospheric mercury measurement methods, Water Air Soil Poll., 80, 611-620, doi:10.1007/bf01189713, 1995.

Seigneur, C. and Lohman, K.: Effect of bromine chemistry on the atmospheric mercury cycle, J. Geophys. Res.-Atmos., 113, D23309, doi:10.1029/2008jd010262, 2008.

Selin, N. E.: Global biogeochemical cycling of mercury: a review, Annu. Rev. Env. Resour., 34, 43-63, doi:10.1146/annurev.environ.051308.084314, 2009.

Selin, N. E.: Global change and mercury cycling: Challenges for implementing a global mercury treaty, Environ. Toxicol. Chem., 33, 1202-1210, doi:10.1002/etc.2374, 2014.

Selin, N. E., Jacob, D. J., Park, R. J., Yantosca, R. M., Strode, S., Jaeglé, L., and Jaffe, D.: Chemical cycling and deposition of atmospheric mercury: Global constraints 
from observations, J. Geophys. Res.-Atmos., 112, D02308, doi:10.1029/2006jd007450, 2007.

Selin, N. E., Jacob, D. J., Yantosca, R. M., Strode, S., Jaeglé, L., and Sunderland, E. M.: Global 3-D land-ocean-atmosphere model for mercury: Present-day versus preindustrial cycles and anthropogenic enrichment factors for deposition, Global Biogeochem. Cy., 22, GB2011, doi:10.1029/2007gb003040, 2008.

Shetty, S. K., Lin, C.-J., Streets, D. G., and Jang, C.: Model estimate of mercury emission from natural sources in East Asia, Atmos. Environ., 42, 8674-8685, doi:10.1016/j.atmosenv.2008.08.026, 2008.

Sheu, G.-R., Lin, N.-H., Wang, J.-L., Lee, C.-T., Ou Yang, C.-F., and Wang, S.-H.: Temporal distribution and potential sources of atmospheric mercury measured at a high-elevation background station in Taiwan, Atmos. Environ., 44, 2393-2400, doi:10.1016/j.atmosenv.2010.04.009, 2010.

Slemr, F., Seiler, W., and Schuster, G.: Latitudinal distribution of mercury over the Atlantic Ocean, J. Geophys. Res.-Oceans, 86, 1159-1166, doi:10.1029/JC086iC02p01159, 1981.

Slemr, F., Brunke, E.-G., Ebinghaus, R., and Kuss, J.: Worldwide trend of atmospheric mercury since 1995, Atmos. Chem. Phys., 11, 4779-4787, doi:10.5194/acp-11-4779-2011, 2011.

Slemr, F., Brunke, E.-G., Whittlestone, S., Zahorowski, W., Ebinghaus, R., Kock, H. H., and Labuschagne, C.: ${ }^{222}$ Rn-calibrated mercury fluxes from terrestrial surface of southern Africa, Atmos. Chem. Phys., 13, 6421-6428, doi:10.5194/acp-13-64212013, 2013.

Slemr, F., Angot, H., Dommergue, A., Magand, O., Barret, M., Weigelt, A., Ebinghaus, R., Brunke, E.-G., Pfaffhuber, K. A., Edwards, G., Howard, D., Powell, J., Keywood, M., and Wang, F.: Comparison of mercury concentrations measured at several sites in the Southern Hemisphere, Atmos. Chem. Phys., 15, 31253133, doi:10.5194/acp-15-3125-2015, 2015.

Smith-Downey, N. V., Sunderland, E. M., and Jacob, D. J.: Anthropogenic impacts on global storage and emissions of mercury from terrestrial soils: Insights from a new global model, J. Geophys. Res.-Biogeo., 115, G03008, doi:10.1029/2009jg001124, 2010.

Soerensen, A. L., Skov, H., Jacob, D. J., Soerensen, B. T., and Johnson, M. S.: Global concentrations of gaseous elemental mercury and reactive gaseous mercury in the marine boundary layer, Environ. Sci. Technol., 44, 7425-7430, doi:10.1021/es903839n, 2010a.

Soerensen, A. L., Sunderland, E. M., Holmes, C. D., Jacob, D. J., Yantosca, R. M., Skov, H., Christensen, J. H., Strode, S. A., and Mason, R. P.: An improved global model for air-sea exchange of mercury: high concentrations over the North Atlantic, Environ. Sci. Technol., 44, 8574-8580, doi:10.1021/es102032g, 2010 b.

Soerensen, A. L., Jacob, D. J., Streets, D. G., Witt, M. L. I., Ebinghaus, R., Mason, R. P., Andersson, M., and Sunderland, E. M.: Multi-decadal decline of mercury in the North Atlantic atmosphere explained by changing subsurface seawater concentrations, Geophys. Res. Lett., 39, L21810, doi:10.1029/2012g1053736, 2012.

Soerensen, A. L., Mason, R. P., Balcom, P. H., and Sunderland, E. M.: Drivers of surface ocean mercury concentrations and air-sea exchange in the West Atlantic Ocean, Environ. Sci. Technol., 47, 7757-7765, doi:10.1021/es401354q, 2013.
Stamenkovic, J. and Gustin, M. S.: Nonstomatal versus stomatal uptake of atmospheric mercury, Environ. Sci. Technol., 43, 13671372, doi:10.1021/es801583a, 2009.

Steffen, A., Douglas, T., Amyot, M., Ariya, P., Aspmo, K., Berg, T., Bottenheim, J., Brooks, S., Cobbett, F., Dastoor, A., Dommergue, A., Ebinghaus, R., Ferrari, C., Gardfeldt, K., Goodsite, M. E., Lean, D., Poulain, A. J., Scherz, C., Skov, H., Sommar, J., and Temme, C.: A synthesis of atmospheric mercury depletion event chemistry in the atmosphere and snow, Atmos. Chem. Phys., 8, 1445-1482, doi:10.5194/acp-8-1445-2008, 2008.

Steffen, A., Scherz, T., Olson, M., Gay, D., and Blanchard, P.: A comparison of data quality control protocols for atmospheric mercury speciation measurements, J. Environ. Monit., 14, 752765, doi:10.1039/c2em10735j, 2012.

Steffen, A., Bottenheim, J., Cole, A., Ebinghaus, R., Lawson, G., and Leaitch, W. R.: Atmospheric mercury speciation and mercury in snow over time at Alert, Canada, Atmos. Chem. Phys., 14, 2219-2231, doi:10.5194/acp-14-2219-2014, 2014.

Stein, E. D., Cohen, Y., and Winer, A. M.: Environmental distribution and transformation of mercury compounds, Crit. Rev. Env. Sci. Tec., 26, 1-43, doi:10.1080/10643389609388485, 1996.

Streets, D. G., Zhang, Q., and Wu, Y.: Projections of global mercury emissions in 2050, Environ. Sci. Technol., 43, 2983-2988, doi:10.1021/es802474j, 2009.

Streets, D. G., Devane, M. K., Lu, Z., Bond, T. C., Sunderland, E. M., and Jacob, D. J.: All-time releases of mercury to the atmosphere from human activities, Environ. Sci. Technol., 45, 1048510491, doi:10.1021/es202765m, 2011.

Strode, S. A., Jaeglé, L., Selin, N. E., Jacob, D. J., Park, R. J., Yantosca, R. M., Mason, R. P., and Slemr, F.: Air-sea exchange in the global mercury cycle, Global Biogeochem. Cy., 21, GB1017, doi:10.1029/2006gb002766, 2007.

Strode, S. A., Jaeglé, L., Jaffe, D. A., Swartzendruber, P. C., Selin, N. E., Holmes, C., and Yantosca, R. M.: Trans-Pacific transport of mercury, J. Geophys. Res.-Atmos., 113, D15305, doi:10.1029/2007jd009428, 2008.

Subir, M., Ariya, P. A., and Dastoor, A. P.: A review of uncertainties in atmospheric modeling of mercury chemistry I. Uncertainties in existing kinetic parameters - Fundamental limitations and the importance of heterogeneous chemistry, Atmos. Environ., 45, 5664-5676, doi:10.1016/j.atmosenv.2011.04.046, 2011.

Subir, M., Ariya, P. A., and Dastoor, A. P.: A review of the sources of uncertainties in atmospheric mercury modeling II. Mercury surface and heterogeneous chemistry - A missing link, Atmos. Environ., 46, 1-10, doi:10.1016/j.atmosenv.2011.07.047, 2012.

Sunderland, E. M., Krabbenhoft, D. P., Moreau, J. W., Strode, S. A., and Landing, W. M.: Mercury sources, distribution, and bioavailability in the North Pacific Ocean: Insights from data and models, Global Biogeochem. Cy., 23, GB2010, doi:10.1029/2008gb003425, 2009.

Temme, C., Ebinghaus, R., Kock, H. H., Schwerin, A., and Bieber, E.: Field intercomparison of mercury measurements within EMEP (executive summary), available at: http://www. nilu.no/projects/ccc/qa/files/EMEP-QA_Hg_UBA.doc (last access: 25 June 2015), 2006.

Timonen, H., Ambrose, J. L., and Jaffe, D. A.: Oxidation of elemental $\mathrm{Hg}$ in anthropogenic and marine airmasses, Atmos. Chem. Phys., 13, 2827-2836, doi:10.5194/acp-13-2827-2013, 2013. 
Tørseth, K., Aas, W., Breivik, K., Fjæraa, A. M., Fiebig, M., Hjellbrekke, A. G., Lund Myhre, C., Solberg, S., and Yttri, K. E.: Introduction to the European Monitoring and Evaluation Programme (EMEP) and observed atmospheric composition change during 1972-2009, Atmos. Chem. Phys., 12, 5447-5481, doi:10.5194/acp-12-5447-2012, 2012.

Travnikov, O. and Ilyin, I.: The EMEP/MSC-E mercury modeling system, in: Mercury Fate and Transport in the Global Atmosphere, edited by: Mason, R. and Pirrone, N., Springer US, New York, NY, USA, 571-587, 2009.

Ulrych, T., Sacchi, M., and Woodbury, A.: A Bayes tour of inversion: A tutorial, Geophysics, 66, 55-69, doi:10.1190/1.1444923, 2001.

Valente, R. J., Shea, C., Lynn Humes, K., and Tanner, R. L.: Atmospheric mercury in the Great Smoky Mountains compared to regional and global levels, Atmos. Environ., 41, 1861-1873, doi:10.1016/j.atmosenv.2006.10.054, 2007.

van der Werf, G. R., Randerson, J. T., Giglio, L., Collatz, G. J., Mu, M., Kasibhatla, P. S., Morton, D. C., DeFries, R. S., Jin, Y., and van Leeuwen, T. T.: Global fire emissions and the contribution of deforestation, savanna, forest, agricultural, and peat fires (19972009), Atmos. Chem. Phys., 10, 11707-11735, doi:10.5194/acp10-11707-2010, 2010.

Wan, Q., Feng, X. B., Lu, J. L., Zheng, W., Song, X. J., Han, S. J., and $\mathrm{Xu}, \mathrm{H} .:$ Atmospheric mercury in Changbai Mountain area, northeastern China I. The seasonal distribution pattern of total gaseous mercury and its potential sources, Environ. Res., 109, 201-206, doi:10.1016/j.envres.2008.12.001, 2009.

Wang, F., Saiz-Lopez, A., Mahajan, A. S., Gómez Martín, J. C., Armstrong, D., Lemes, M., Hay, T., and Prados-Roman, C.: Enhanced production of oxidised mercury over the tropical Pacific Ocean: a key missing oxidation pathway, Atmos. Chem. Phys., 14, 1323-1335, doi:10.5194/acp-14-1323-2014, 2014.

Wang, S., Zhang, L., Wang, L., Wu, Q., Wang, F., and Hao, J.: A review of atmospheric mercury emissions, pollution and control in China, Front. Environ. Sci. Eng., 8, 631-649, doi:10.1007/s11783-014-0673-x, 2014.

Wang, X., Lin, C.-J., and Feng, X.: Sensitivity analysis of an updated bidirectional air-surface exchange model for elemental mercury vapor, Atmos. Chem. Phys., 14, 6273-6287, doi:10.5194/acp-14-6273-2014, 2014

Weigelt, A., Temme, C., Bieber, E., Schwerin, A., Schuetze, M., Ebinghaus, R., and Kock, H. H.: Measurements of atmospheric mercury species at a German rural background site from 2009 to 2011 - methods and results, Environ. Chem., 10, 102-110, doi:10.1071/EN12107, 2013.

Weiss-Penzias, P., Jaffe, D. A., Swartzendruber, P., Dennison, J. B., Chand, D., Hafner, W., and Prestbo, E.: Observations of Asian air pollution in the free troposphere at Mount Bachelor Observatory during the spring of 2004, J. Geophys. Res.-Atmos., 111, D10304, doi:10.1029/2005jd006522, 2006.

Wesely, M. L.: Parameterization of surface resistances to gaseous dry deposition in regional-scale numerical models, Atmos. Environ., 23, 1293-1304, doi:10.1016/0004-6981(89)90153-4, 1989.
Wilke, C. R. and Chang, P.: Correlation of diffusion coefficients in dilute solutions, AIChE J., 1, 264-270, doi:10.1002/aic.690010222, 1955.

Wunsch, C.: Discrete inverse and state estimation problems: with geophysical fluid applications, Cambridge University Press, New York, USA, 43-69, 2006.

Xiao, X., Prinn, R. G., Fraser, P. J., Weiss, R. F., Simmonds, P. G., O'Doherty, S., Miller, B. R., Salameh, P. K., Harth, C. M., Krummel, P. B., Golombek, A., Porter, L. W., Butler, J. H., Elkins, J. W., Dutton, G. S., Hall, B. D., Steele, L. P., Wang, R. H. J., and Cunnold, D. M.: Atmospheric three-dimensional inverse modeling of regional industrial emissions and global oceanic uptake of carbon tetrachloride, Atmos. Chem. Phys., 10, 10421-10434, doi:10.5194/acp-10-10421-2010, 2010.

Xu, X., Yang, X., R. Miller, D., Helble, J. J., and Carley, R. J.: Formulation of bi-directional atmosphere-surface exchanges of elemental mercury, Atmos. Environ., 33, 4345-4355, doi:10.1016/S1352-2310(99)00245-9, 1999.

Zepp, R. G., Faust, B. C., and Hoigne, J.: Hydroxyl radical formation in aqueous reactions ( $\mathrm{pH} 3-8$ ) of iron(II) with hydrogen peroxide: the photo-Fenton reaction, Environ. Sci. Technol., 26 , 313-319, doi:10.1021/es00026a011, 1992.

Zhang, H. and Lindberg, S. E.: Sunlight and Iron(III)-induced photochemical production of dissolved gaseous mercury in freshwater, Environ. Sci. Technol., 35, 928-935, doi:10.1021/es001521p, 2001.

Zhang, H., Fu, X. W., Lin, C.-J., Wang, X., and Feng, X. B.: Observation and analysis of speciated atmospheric mercury in ShangriLa, Tibetan Plateau, China, Atmos. Chem. Phys., 15, 653-665, doi:10.5194/acp-15-653-2015, 2015.

Zhang, L., Blanchard, P., Gay, D. A., Prestbo, E. M., Risch, M. R., Johnson, D., Narayan, J., Zsolway, R., Holsen, T. M., Miller, E. K., Castro, M. S., Graydon, J. A., Louis, V. L. St., and Dalziel, J.: Estimation of speciated and total mercury dry deposition at monitoring locations in eastern and central North America, Atmos. Chem. Phys., 12, 4327-4340, doi:10.5194/acp-12-43272012, 2012.

Zhang, Y., Jaeglé, L., van Donkelaar, A., Martin, R. V., Holmes, C. D., Amos, H. M., Wang, Q., Talbot, R., Artz, R., Brooks, S., Luke, W., Holsen, T. M., Felton, D., Miller, E. K., Perry, K. D., Schmeltz, D., Steffen, A., Tordon, R., Weiss-Penzias, P., and Zsolway, R.: Nested-grid simulation of mercury over North America, Atmos. Chem. Phys., 12, 6095-6111, doi:10.5194/acp12-6095-2012, 2012.

Zhang, Y., Jaeglé, L., Thompson, L., and Streets, D. G.: Six centuries of changing oceanic mercury, Global Biogeochem. Cy., 28, 1251-1261, doi:10.1002/2014gb004939, 2014 